Published: Dormady, N., Hoyt, M. Roa-Henriquez, A. \& Welch, W. 2019. Who Pays for Retail Electric Deregulation?: Evidence of Cross-Subsidization from Complete Bill Data. The Energy Journal, 40(2): 161-194. https://doi.org/10.5547/01956574.40.2.ndor

\title{
Who Pays for Retail Electric Deregulation?: Evidence of Cross-Subsidization from Complete Bill Data ${ }^{\dagger}$
}

\author{
July 6, 2018
}

\author{
Noah Dormady ${ }^{\dagger \dagger}$ \\ John Glenn College of Public Affairs \\ The Ohio State University \\ Alfredo Roa-Henriquez \\ John Glenn College of Public Affairs \\ The Ohio State University
}

\author{
Matthew Hoyt \\ Exeter Associates \\ William Welch \\ College of Education and Human Ecology \\ The Ohio State University
}

\begin{abstract}
Retail electric deregulation has been identified in the literature to have favorable price impacts to businesses and households because of the introduction of competition into rate-setting. Those studies often ignore the important role of regulatory intervention. They are also generally national or multi-state aggregated studies that ignore state- and utility-specific dynamics, and most rely on Energy Information Administration (EIA) price data that does not account for riders and surcharges on consumer bills, which can total more than 60 percent of bills. Using a unique panel of representative, complete electricity bill data from the Public Utilities Commission of Ohio (PUCO), this paper provides a multi-utility panel regression analysis of the effect of retail deregulation on total electric bills in Ohio. The results identify two main sources of cross-subsidization that have generally cancelled out the favorable effects of restructuring. Both types of cross-subsidies result in substantial burden shifts to residential consumers.
\end{abstract}

Keywords: Deregulation; Public Utilities; Electricity Markets; Cross-subsidization; Divestiture

JEL Classifications: H23; L43; L51; L94

\footnotetext{
$\dagger$ The authors thank Andrea Terry, Zheng Zhou, Rui Bo and Jason Waters at the Midcontinent Independent Systems Operator (MISO), Serhan Ogur, Edward "Ned" Hill, Zhongnan Jiang, and Michael Giberson for their helpful conversations, comments and insights. The findings, conclusions, and recommendations expressed in this paper are the product of research by the authors and do not represent the views of the John Glenn College of Public Affairs, The Ohio State University, or Exeter Associates.

†† Corresponding Author: 1810 College Rd., Columbus OH, 43210; email: dormady.1@ osu.edu; Ph.: 614-688-1668.
} 


\section{Introduction}

The answer to the question "do retail customers benefit?" has long eluded researchers studying the emergence, implementation, and impact of electric deregulation, or restructuring. Lawmakers and other original proponents of reform argued that improved resource allocation as a result of restructuring would trickle down to customers, resulting in reduced electric rates to both businesses and households (Winston, 1993). Today, empirical support for these claims remains frustratingly opaque (Eto et al., 2006; Joskow, 2008; Kwoka, 2008; Swadley and Yucel, 2011). As Bushnell, Mansur, and Novan (2017) note in a recent literature review, "arguably, the most fundamental question regarding restructuring relates to its impact on consumers' electricity prices. Here, again, the empirical research is somewhat muddled" (p. 11). In this paper, we provide an empirical analysis of the impact of retail electric restructuring using a unique representative total bill dataset from Ohio. We evaluate the impact of restructuring on residential, commercial and industrial customers, with an explicit focus on cross-subsidization. We find robust evidence of two forms of cross-subsidization, inter-class and inter-firm, which we call Type I and II crosssubsidization.

Our results indicate that the observed cross-subsidization outcomes can be directly attributed to the manner by which Ohio implemented retail restructuring. Rather than requiring utilities to functionally separate their generation assets (also referred to as unbundling or divestiture - a critically-important stage in the restructuring process), Ohio's restructuring process allowed utilities to simply corporately separate those assets by selling them to a subsidiary. At the same time, Ohio retained a rate-setting mechanism that allowed utilities to charge non-bypassable riders and surcharges. We find that, by adding non-germane riders (in some cases almost three 
dozen) to customer bills, Ohio's utilities were able to recover the post-shale boom losses of their predominantly coal-fired deregulated generation subsidiaries.

We also observe unequal allocation of these costs between customer classes. Accordingly, we see evidence of inter-firm cross-subsidization as we detect a highly robust inverse relationship between the price of natural gas and the actual retail price of electricity. Historic declines in the marginal input fuel, natural gas, resulted in loses to deregulated coal plants. Riders and surcharges on regulated utility customer bills provided the pathway to recover those loses. We also see evidence of inter-class cross-subsidization as we observe robust differences in price effect by customer class. We find the same results in a set of companion models based on the wholesale electricity price.

Ohio provides natural experiment conditions that allow us to further investigate these results. One of the major utilities in the state, serving the Cincinnati metro area, pursued functional, rather than corporate separation. Unlike the other distribution utilities, they had no instrumental incentive to pursue cost recovery for affiliate generation through riders. For Cincinnati, we find equally-robust results in the opposite direction, providing further empirical support for the importance of regulatory structure in influencing the outcome of restructuring.

We begin with a concise summary of the empirical literature on retail restructuring and cross-subsidization. We then provide an assessment of our data in comparison to the literature's longstanding reliance on Energy Information Administration (EIA) price data, which does not account for riders and surcharges that flow through to subsidiary corporations. In Section 2, we provide a concise history of Ohio's experience with restructuring and position our work within the larger body of literature. Sections 3 and 4 provide our empirical data and methodology, and Section 
5 provides the empirical results. Section 6 concludes with implications for future research in the field and analysis for other states that have implemented restructuring in similar ways.

\subsection{Prior Empirical Research}

Empirical research on the effect of retail restructuring is inconclusive at best. Apt (2005) found no net impact in a study of price effects for industrial customers. In contrast, Joskow (2006) identified residential and industrial savings associated with retail competition. It has been argued that these and other earlier studies include a variety of empirical and theoretical limitations, including inadequate or imperfect accounting of confounding market and regulatory changes (Kwoka, 2008). Subsequent studies have improved explanatory power and granularity. Swadley and Yücel (2011), using choice participation rates as a measure of retail market competitiveness, determined that retail prices decreased following retail restructuring. Using EIA retail price data and a dynamic panel model of 16 restructured U.S. states and D.C., they found that competition reduced retail price mark-ups relative to wholesale price, indicating improved efficiency. Su (2015), who assessed the impact of retail choice availability on EIA's retail price data using a national panel from 1990 to 2011, found no impact on commercial and industrial customer prices and only short-term price reductions for residential customers. Su attributed these results to rate freezes and lower natural gas fuel costs. ${ }^{1}$

Ros (2017), who assessed the impact of retail competition on average revenue per unit sales using a 72-utility panel from 1972 to 2009 , found that retail restructuring lowered prices, but that the impact varied by customer class. ${ }^{2}$ More specifically, Ros found residential, commercial, and

\footnotetext{
${ }^{1} \mathrm{Su}$ does find that full retail choice (i.e., choice available to all customer classes) does benefit industrial customers, but attributes this result to spillovers from protections put in place for residential customers.

${ }^{2}$ In his study, average revenue per unit sales is a proxy for price, as derived from Federal Energy Regulatory Commission (FERC) Form 1 Data.
} 
industrial price impacts of $-4.3 \%,-8.2 \%$, and $-11.1 \%$, respectively. His results indicate that over time these benefits deteriorate, remain static, and increase for residential, commercial, and industrial customers, respectively. Hartley, Medlock, and Jankovska (2017) employed total bill data from Texas and found a benefit to residential customers from retail choice as compared to non-restructured parts of the state. They attribute this savings to declining service provider costs, reduced price mark-ups, and the increased pass-through of wholesale market costs. Like several other studies, theirs linked retail rates to the cost of the marginal fuel source, natural gas. Other studies of Texas have reached similar conclusions regarding the effect of natural gas price on rates (McKearin, 2015; Whitworth and Zarnikau, 2006; Woo and Zarnikau, 2009).

Empirical research specifically on restructuring and cross-subsidization has been thin. Nagayama (2007) evaluated industrial to residential electric price ratios relative to GDP per capita and maturity of electric market reform in an 83-nation longitudinal study. The findings indicated that market reforms have inconsistent impacts on prices and cross-subsidization depending upon the type of economy and maturity of markets, with the general result suggesting that industrial prices fell most after reform in developing countries. Erdogdu (2011) expanded on Nagayama's work by incorporating developed countries and additional fuel-cost controls into a 63-nation panel of price-cost margin and cross-subsidy ratios from 1982 to 2009. Again, the results suggested that most market reforms appear to have inconsistent, country-specific effects. The study also found, however, that the introduction of retail choice increases cross-subsidization in developed countries. ${ }^{3}$ Erdogdu interprets this as decreased efficiency.

\footnotetext{
${ }^{3}$ The exact direction of the effect is unclear due to the use of the absolute value of deviation in price ratio as the dependent variable. Nonetheless, separate models indicate falling residential price-cost margin and insignificant change in industrial customer pricecost margin due to retail choice. This implies that the cross-subsidy increases in favor of residential customers.
} 
Besides empirical assessments, several scholars attribute changes in cross-subsidization to market reform. Su (2015) theorized that cross-subsidization from residential to industrial customers dissipated after the introduction of retail competition, partially explaining residential cost decreases. Hartley, Medlock, and Jankovska (2017) argued that the elimination of crosssubsidization from commercial to residential customers partially explains decreases in commercial and industrial costs after retail restructuring. Of crucial importance is the explanation for the functional mechanism by which restructuring would cause, or change, inequalities in the relative price of electricity as measured by the inter-class price ratio. This is unfortunately absent or incomplete in all of the available literature due to the absence of thorough cost-of-service allocation information by customer class. While this paper does not solve this longstanding issue, by using final bill data and estimating inter-firm cross-subsidization, it provides some evidence that changes in relative prices across customer class cannot be completely explained by the unwinding of any pre-restructuring cross-subsidies. This is because we also observe significant inter-class differentials in inter-firm cross-subsidization.

\subsection{Improved Metrics}

A critical shortcoming of nearly all prior research is its reliance on EIA 826 data, which provides an incomplete assessment of total bills that residential, industrial, and commercial customers receive. This is because it is based on a simplified ratio of reported distribution utility revenue to customer count, or sales volume. It misses important aspects of complex holding company structures that define nearly every utility in the country. In many cases, EIA data miss indirect costs and other flow-through revenues that all customers see in the form of non-bypassable 
riders and surcharges, which can amount to over 60 percent of the total bill. ${ }^{4}$ With the exception of Hartley, Medlock, and Jankovska (2017), all previous empirical research on electric restructuring in the U.S. has relied on bill proxy data rather than total bill data.

Relatedly, empirical work in the U.S. has generally relied on aggregate multi-state panel data. In so doing, it has overlooked key state- and utility-level policy interventions (like divestiture). It also oversimplifies restructuring status by reducing or ignoring variation both within and between states. The exclusion of these crucial details can produce non-trivial identification error. For example, recent multi-state longitudinal studies such as Su (2015) and Ros (2017) used EIA's Status of Electricity Restructuring reports to code the year of restructuring. This report is based upon passage of enabling legislation - rather than when the legislation was actually implemented. Ros's panel data codes Ohio restructuring as beginning in 2001, and his panel ends in 2009. But in Ohio, as discussed below, the actual tariff mechanism that permitted customer switching coincided with the passage of Senate Bill 221 in 2008. As a result, no real switching occurred during the last nine years of his panel, representing the entirety of his policy intervention period for the State of Ohio. This begs the question of what these prior studies are actually measuring, as it is likely that they are conflating secondary market effects with restructuring effects.

The Public Utilities Commission of Ohio (PUCO) publishes detailed representative total bill data on a monthly basis for all customer classes separately. Using this data, this paper provides a more fine-grained panel analysis of seven metro areas in the State of Ohio corresponding to utility service areas, accounting for important subtleties omitted from prior research (e.g., actual

\footnotetext{
${ }^{4}$ Non-bypassable riders are revenues collected by the distribution utility that appear on all customer bills regardless of whether the customer has "switched" to obtaining supply from a marketer or not. The interested reader is encouraged to see 155 FERC 961,101 , and 155 FERC II 61,102 (April 27, 2016) or Dormady (2017) for a detailed assessment of two large rider proposals that were overturned by FERC predominantly because customers who switched away from default service could not opt-out of them. They provide a thorough assessment of the issue of non-bypassability.
} 
restructuring implementation, divestiture). This paper also provides utility-level assessments of the impact of retail restructuring and incorporates greater detail than prior studies by incorporating explanatory variables for zonal load-weighted wholesale price, actual final delivery price of fuel inputs as opposed to futures prices that do not account for the costs of shipping fuel commodities, and all utility operational costs inclusive of labor, capital, amortization, and depreciation.

Before introducing the empirical analysis, the next section of this paper provides a general background on electricity deregulation, with a very brief summary of Ohio's experience. It then explains the conceptual difference between two types of cross-subsidization, necessary for understanding the empirical and theoretical contributions of this paper.

\section{Theoretical Foundation}

\subsection{The Promise of Electric Restructuring}

Electric restructuring consists of a variety of market reforms intended to improve economic efficiency. The canonical model of reform in developed countries includes unbundling competitive market segments such as generation, introducing new or expanded wholesale markets, establishing rules and independent oversight that supports open transmission access, and initiating either competitive generation procurement or retail choice (Chao and Huntington, 1998; Hunt, 2002; Joskow and Schmalensee, 1983; Joskow, 1989; 1998; 2006). ${ }^{5}$ The intended outcomes for retail rate determination and cost allocation are, in theory, nearly identical to the principles of "cost of service" regulation for vertical monopolies: rates should be transparent, encourage investment, avoid cross-subsidies, and foster efficient decision-making by customers and utilities alike

\footnotetext{
${ }^{5}$ The literature principally deals with two forms of unbundling: corporate separation, and full divestiture (Bushnell, Mansur and Saravia, 2008; Ishii and Yan, 2007; Kwoka, et. al., 2010; Mansur, 2007). Empirical evidence in support of either approach is limited.
} 
(Phillips, 1993). ${ }^{6}$ A longstanding and well-respected literature has justified a healthy skepticism that these goals can be achieved under traditional regulatory designs (Averch and Johnson, 1962; Peltzman, 1976; Posner, 1974; Stigler and Friedland, 1962). The claims of proponents of restructuring thus highlighted these well-established shortcomings of regulatory systems, arguing that market-based reforms would improve efficiency to all customers. Although theorists believed scale economies, principally benefiting the commercial and industrial classes, would be unaffected by restructuring, both scholars and practitioners also argued that reforms would "reduce the magnitude of the subsidies and gradually eliminate those that do not have broad public support" (Joskow, 1998, p. 45). This is due to the "sunlight" of transparent and impartial open markets. ${ }^{7}$

\subsection{Retail Restructuring (Customer Choice)}

Retail (rather than wholesale) restructuring is an important subcomponent of overall electricity market reform because it establishes the mechanism by which the benefits of wholesale restructuring are realized by retail customers. After implementing retail restructuring, distribution utilities are expected to competitively procure generation. This can be through contracts or auctions, or, alternatively, by allowing customers more-direct access to wholesale markets. The latter includes wheeling arrangements and customer-directed procurement through competing retail suppliers (e.g., brokers or marketers) who purchase generation from wholesale markets on behalf of customers. The cost-effectiveness of customer choice, as compared to other competitive procurement strategies, is often questioned in the literature (Defeuilley, 2009; Joskow, 2000; Joskow and Schmalensee, 1983; Morey and Kirsch, 2016). Nevertheless, a significant plurality of

\footnotetext{
${ }^{6}$ Perhaps the biggest theoretic difference is a shift from an average cost to a marginal cost basis of rate determination (Borenstein and Bushnell, 2015; Woo and Zarnikau, 2009).

${ }^{7}$ For example, electric rates are often used to support rural customers, small businesses, and low-income customers, provide economic incentives to attract new industry, prop-up local fuel sources (especially coal), and promulgate environmental policy, among other political, social, and economic interventions (Joskow, 1998).
} 
states and countries that undertook wholesale restructuring also adopted customer choice in some capacity. $^{8}$

The literature articulates several potential benefits of consumer choice. For example, it can stimulate new products (e.g., aggregation) and services (e.g., green portfolios) as well as create liquidity in wholesale markets (Littlechild, 2000; 2002). Ohio adopted both forms of retail restructuring: auctions and customer choice. Utilities in Ohio adopted the use of Competitive Bidding Price (CBP) auctions to procure default, standard service offer (SSO) supply. ${ }^{9}$ Both supply mechanisms procure generation from the same competitive wholesale markets. Consequently, $\mathrm{CBP}$ and retail choice offer prices should converge to the same average costs for generation, excepting for differences in competitive business practices. ${ }^{10}$

\subsection{Restructuring in Ohio}

Ohio, like many of its peers in the U.S. and other developed countries, followed a winding and imperfect path to implementing electric market deregulation. ${ }^{11}$ It was driven in part by declining marginal costs for wholesale power in the 1990s as compared to the higher average cost prices paid by retail customers. Industrial and commercial customers, in response, lobbied for market reforms and greater wholesale market access. Ohio initiated restructuring in 1999 with the passage of Senate Bill (SB) 3, which started a five-year "market development" period during which retail rates remained frozen and utilities were allowed to recover stranded costs through transition

\footnotetext{
${ }^{8}$ According to the EIA, 20 U.S. states have adopted some form of liberalized retail choice. The extent of availability differs (e.g., limitations to certain customer classes or participation caps) (EIA-861, 2016).

${ }^{9}$ Retail choice allows customers to elect to receive energy services from an alternative, certified retail electric supplier (CRES). The SSO is the default option for customers that do not choose an alternative supplier.

${ }^{10}$ For example, prices may diverge from cost in response to product and service offerings (e.g., renewables, line insurance), hedging strategies, and other contract terms (e.g., duration, termination fees). In Ohio today, retail choice offers are generally slightly higher than SSO offers. This comports with the recent work of Tsai and Tsai (2018) who observe an almost oligopolistic, or Bertrand-like price signaling between the regulated SSO offer and CRES offerings in their study of retail choice in Connecticut.

${ }^{11}$ See the works of Littlechild (2008), Thomas, Lendel, and Park (2014), and Dormady, Jiang, and Hoyt (2018) for a more thorough overview of Ohio's deregulation process.
} 
charges. The PUCO subsequently delayed retail markets via "Rate Stabilization Plans" (RSPs) until, in 2008, Ohio passed SB 221.

SB 221 officially ended traditional cost-of-service ratemaking for generation and established market-based retail ratemaking, including retail choice markets. Under the CBP auction design, wholesale providers bid to supply tranches of each distribution utility's SSO obligation, putting pressure on the supply-component of SSO rates to align with wholesale prices. Like virtually all states and countries that have restructured to-date, Ohio did not follow the strict guidance of early theorists (Hunt, 2002; Joskow, 2008; Joskow and Schmalensee, 1983) in two important ways.

First, Ohio did not require functional separation (divestiture) of generation from the distribution utilities, instead allowing "corporate" separation (Dormady, Jiang and Hoyt, 2018). This permitted distribution utilities to maintain ownership of their generation fleets (predominantly coal) in arms-length subsidiaries (Dormady, 2017). Functional separation is critically-important to restructuring (Morey and Kirsch, 2016). In its absence, distribution utilities can be tempted to use their regulated retail operations to cross-subsidize their deregulated generation business. Second, Ohio retained regulatory intervention in the form of "Electric Security Plans" (ESPs). ${ }^{12}$ ESPs reduced the procedural requirements of utilities for gaining approval for additional cost recovery, allowing what practitioners call "single issue ratemaking." Essentially, SB 221 made it easier for utilities to obtain non-bypassable riders and surcharges on customer bills (even those who switched to a competitive supplier) in support of an aging generation fleet still on their balance sheets. Restructuring in Ohio mirrors the "real world" experience of many other states (e.g., New York,

\footnotetext{
${ }^{12}$ ESPs allow utilities to pursue non-bypassable riders, tariffs, and other price interventions during the SSO determination process. For example, AEP's most recent ESP filing includes at least nine new or modified non-bypassable riders and tariffs, including an "Automaker Credit Rider," a "Basic Transmission Cost Recovery provision for County Fairgrounds" rider, and an "Economic Development Rider" (PUCO, 2018). Ohio also established a competitive "Market Rate Offer" (MRO) mechanism for setting SSO rates but did not obligate its use.
} 
Illinois, Pennsylvania), many of which are still grappling with financial support to incumbent utilities and resources. $^{13}$

\subsection{Inter-Class and Inter-Firm Cross-Subsidization}

We examine two types of cross-subsidization, which we designate Type I and II, that can affect customer bills:

1. Type I cross-subsidy identifies cross-subsidization between customer classes (i.e., residential, industrial, and commercial) and occurs on the consumption/demand side. After retail restructuring in Ohio, SSO customers in all classes observe the same generation component price: the price set by the CBP procurement auction which, in turn, is tied to the wholesale market price. Transmission and Distribution (T\&D) costs remain unchanged, as do load-curve related differences in average generation costs. ${ }^{14}$ In other words, after retail deregulation, the only determinants of inter-class difference in the final retail price other than usage is the regulated component of the bill. Evidence of Type I crosssubsidization before or after restructuring would be observed when the relative marginal cost of retail electric prices between any two customer classes changes, holding wholesale costs unchanged. Regulators may approve Type I cross-subsidies outside of the generation component for economic development purposes or for alternative political rationales.

2. Type II cross-subsidy identifies cross-subsidization between consumers and utilityaffiliated generation units. This type occurs on the production side. Utilities that only corporately separate, rather than functionally divest, their generation units retain affiliation with the units through a holding company structure, often as a subsidiary corporation. For example, AEP created AEP Generation Services Corporation, and FirstEnergy created FirstEnergy Generation, LLC to retain ownership of their legacy coal units. Type II crosssubsidies would tend to be observed when utility-affiliated generation is less profitable

\footnotetext{
${ }^{13}$ For example, several states have implemented "Zero Emission Credit" payments to nuclear facilities which, in effect, subsidize the recipient facility's participation in wholesale markets. As another example, California regulators have given state investorowned utilities permission to build fully regulated power plants in direct competition with independent power producers. The competition from resources with guaranteed revenue has caused several independent plants to close early (Menezes and Penn, 2017).

${ }^{14}$ For example, the average generation cost for different customer classes will still differ based on relative time-of-use.
} 
than independent, non-utility generation participating in the wholesale markets. Whereas utilities can pursue cost recovery through both the regulated rates on customer bills and the wholesale market, independent generation can only pursue cost recovery through the market. In the presence of a Type II cross-subsidy, customers would be offsetting utility losses through increased retail prices.

\section{Data}

We develop a monthly panel dataset representative of the seven main metropolitan areas in Ohio for the period January 2004 through December 2016. In total, the data includes 1,092 observations, consisting of seven panels across 156 months, and is representative of seven utilities. ${ }^{15}$ We adopt two sets of dependent variables: 1) the marginal price of SSO electricity in cents per kilowatt hour for residential, commercial, and industrial customers; and 2) the marginal price ratios of residential to industrial price, and residential to commercial price. Electricity price data is provided by the PUCO monthly Ohio Utility Rate Survey. Unlike EIA data, the PUCO data provides total electric bills (i.e., a representation of the actual bill that customers pay), inclusive of generation, T\&D, and all other regulatory approved costs such as riders and surcharges. The PUCO reports representative total bills based on fixed consumption levels for each customer class (750 $\mathrm{kWh}$ for residential, 300,000 kWh for commercial, and 6 million $\mathrm{kWh}$ for industrial).

There are a variety of advantages to using total consumer bills (Dormady, Jiang, and Hoyt, 2018; Hartley, Medlock, and Jankovska, 2017). Notably, total bill data includes both direct and indirect costs. EIA marginal prices, on the other hand, are estimates derived by dividing revenues reported by the distribution utility (i.e., the numerator) by total consumption of electricity (i.e., the

\footnotetext{
15 These seven utilities are the FirstEnergy affiliates Toledo Edison (Toledo), Ohio Edison (Akron), and the Cleveland Electric Illuminating Company (CEI) (Cleveland); the AEP affiliates Columbus Southern Power (CSP) (Columbus) and Ohio Power (Canton) (merged effective January 1, 2012); Duke Energy (Cincinnati) (formerly Cinergy Corporation until the acquisition completion date of April 3, 2006); and, Dayton Power \& Light (DP\&L) (Dayton).
} 
denominator). The consumption measure often reports all customers of the distribution utility, including customers who switched to a competitive supplier. The revenue component of the numerator includes only distribution company revenues, excluding revenues obtained on customer bills that flow through to parent companies, arms-length subsidiaries, and corporately separated generation companies (gencos). Thus, EIA's price estimates deflate the numerator. And, by including customers who have switched to competitive suppliers for their generation in the denominator, they can inflate the denominator. Unlike total bill data, EIA data does not allow for complete assessments of cross-subsidization and misses costs associated with flow-through revenues collected for gencos (i.e., Type II). We provide a time series plot of the panel-average inter-class marginal price ratio in Figure 1 for the period both before and after retail deregulation. Individual panels are provided in the Appendix B.

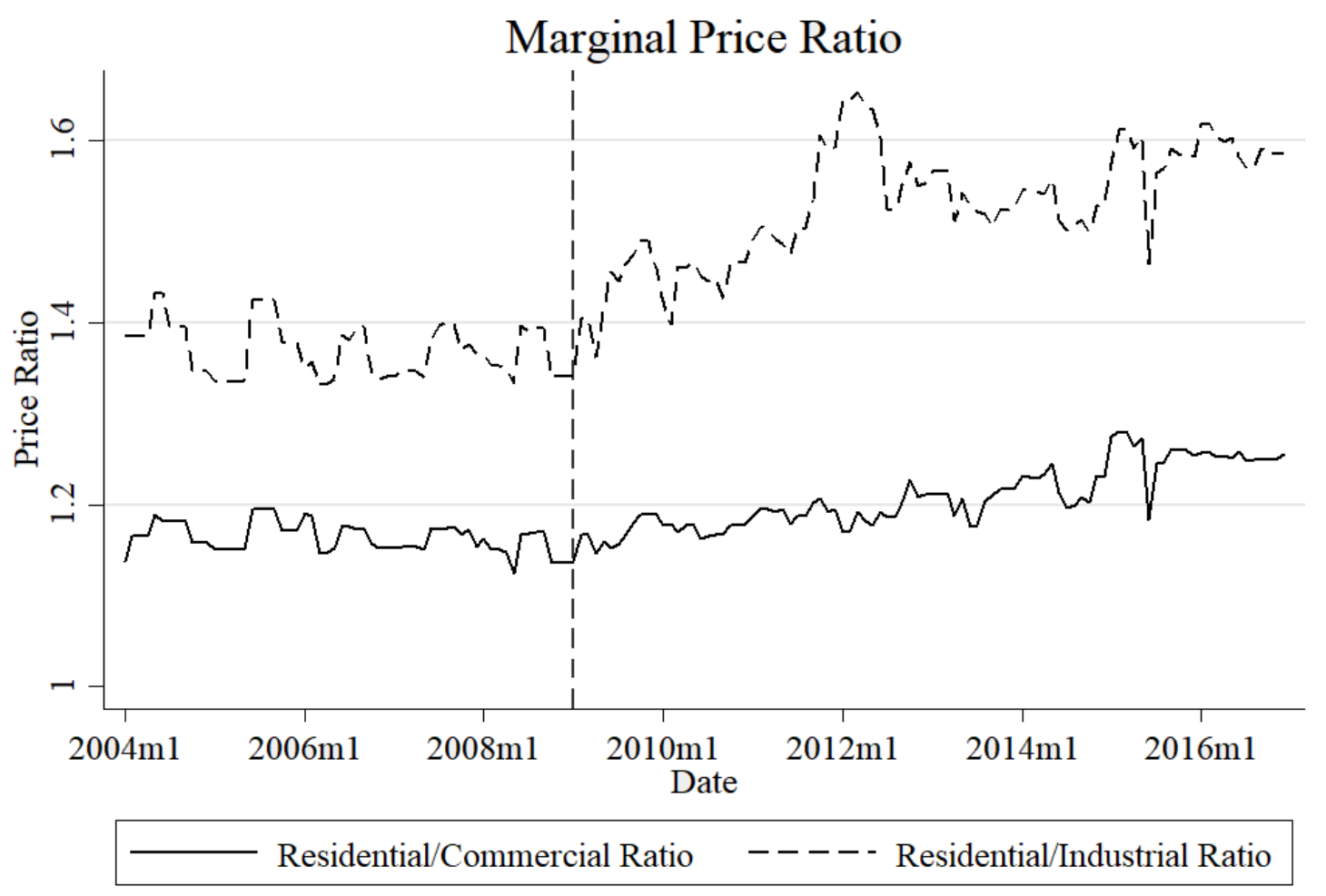

Vertical line indicates implementation of retail electric deregulation beginning January 2009

Figure 1. Statewide Average Inter-class Price Ratio (Pre- and Post-Restructuring) 


\section{Types I and II cross-subsidization are measured empirically using four primary explanatory}

variables: the price of natural gas and coal delivered to utilities in Ohio in million British thermal units (mmBTUs); the wholesale, load-weighted locational marginal price (LMP) of electricity; and a retail restructuring dummy variable. Table 1 and 2 provide descriptions and summary statistics. Use of the final delivery price of both gas and coal input fuels captures transportation costs not picked up in other studies that rely on futures data. ${ }^{16}$ Input fuel pricing data is provided in Figure 2.

Table 1. Data Definitions, Units and Source

\begin{tabular}{|c|c|c|c|}
\hline Variable & Description & Unit & Source \\
\hline Price_Residential & $\begin{array}{l}\text { Monthly indicative residential marginal price by metro area } \\
\text { based on complete bill and usage fixed at } 750 \mathrm{kWh}\end{array}$ & $\mathrm{C} / \mathrm{kWh}$ & PUCO \\
\hline Price_Commercial & $\begin{array}{l}\text { Monthly indicative commercial marginal price by metro area } \\
\text { based on complete bill and usage fixed at } 300,000 \mathrm{kWh}\end{array}$ & $\mathbb{C} / \mathrm{kWh}$ & PUCO \\
\hline Price_Industrial & $\begin{array}{l}\text { Monthly indicative industrial marginal price by metro area } \\
\text { based on complete bill and usage fixed at } 6,000,000 \mathrm{kWh}\end{array}$ & $\mathbb{C} / \mathrm{kWh}$ & PUCO \\
\hline NatGasDeliv_Price & $\begin{array}{l}\text { Monthly wholesale fuel price for natural gas inclusive of } \\
\text { delivery cost }\end{array}$ & $\$ / \mathrm{mmBTU}$ & $\begin{array}{l}\text { EIA, EPM, Table } \\
\text { 4.10.A }\end{array}$ \\
\hline CoalDeliv_Price & Monthly wholesale fuel price for coal inclusive of delivery cost & $\$ / \mathrm{mmBTU}$ & $\begin{array}{l}\text { EIA, EPM, Table } \\
\text { 4.10.A }\end{array}$ \\
\hline$L M P$ & $\begin{array}{l}\text { Hourly PJM and MISO LMPs weighted by hourly load and } \\
\text { aggregated into monthly rates }\end{array}$ & \$/MWh & PJM, MISO \\
\hline Div_Com_Stock & Dollar amount of dividends issued to common stock holders & $\begin{array}{l}\text { Billions } \\
\text { USD }\end{array}$ & FERC Form 1/3-Q \\
\hline Div_Pref_Stock & Dollar amount of dividends issued to preferred stock holders & $\begin{array}{l}\text { Billions } \\
\text { USD }\end{array}$ & FERC Form 1/3-Q \\
\hline Tot_Op_Expn & $\begin{array}{l}\text { Dollar amount of operations expenses for the reporting electric } \\
\text { entity, inclusive of capital, labor, O\&M, amortization \& } \\
\text { depreciation }\end{array}$ & $\begin{array}{l}\text { Billions } \\
\text { USD }\end{array}$ & FERC Form 1/3-Q \\
\hline Res_Sales_Mwh & $\begin{array}{l}\text { Megawatt-hours provided to residential customers by the } \\
\text { reporting electric entity }\end{array}$ & $\begin{array}{l}\text { Millions } \\
\text { MWh }\end{array}$ & FERC Form 1/3-Q \\
\hline Comm_Sales_Mwh & $\begin{array}{l}\text { Megawatt-hours provided to small commercial firms by the } \\
\text { reporting electric entity }\end{array}$ & $\begin{array}{l}\text { Millions } \\
\text { MWh }\end{array}$ & FERC Form 1/3-Q \\
\hline Ind_Sales_Mwh & $\begin{array}{l}\text { Megawatt-hours provided to large commercial firms by the } \\
\text { reporting electric entity }\end{array}$ & $\begin{array}{l}\text { Millions } \\
\text { MWh }\end{array}$ & FERC Form 1/3-Q \\
\hline
\end{tabular}

\footnotetext{
${ }^{16}$ This would include non-trivial costs collected by rail transport such as Berkshire Hathaway's BNSF Railway Co.
} 
Table 2. Summary Statistics

\begin{tabular}{lcccc}
\hline \hline Variable Name & Mean & Std. Dev. & Min & Max \\
\hline Price_Residential & 13.0492 & 1.6368 & 8.7707 & 18.5557 \\
Price_Commercial & 11.1239 & 1.9933 & 6.1407 & 16.9645 \\
Price_Industrial & 9.2160 & 2.2724 & 5.4294 & 16.2932 \\
NatGasDeliv_Price & 6.5781 & 3.8801 & 1.5035 & 17.7917 \\
CoalDeliv_Price & 2.1312 & 0.2799 & 1.5495 & 2.7359 \\
LMP & 44.0637 & 13.5698 & 23.9861 & 102.9773 \\
Div_Com_Stock & 0.1307 & 0.0189 & 0.0000 & 0.1345 \\
Div_Pref_Stock & 0.0004 & 0.0043 & 0.0000 & 0.0714 \\
Tot_Op_Expn & 0.1735 & 0.1545 & 0.0300 & 1.2806 \\
Res_Sales_Mwh & 0.5696 & 0.2584 & 0.1480 & 1.4972 \\
Comm_Sales_Mwh & 0.4663 & 0.2373 & 0.0429 & 1.3712 \\
Ind_Sales_Mwh & 0.5691 & 0.2990 & 0.0052 & 1.2957 \\
\hline
\end{tabular}

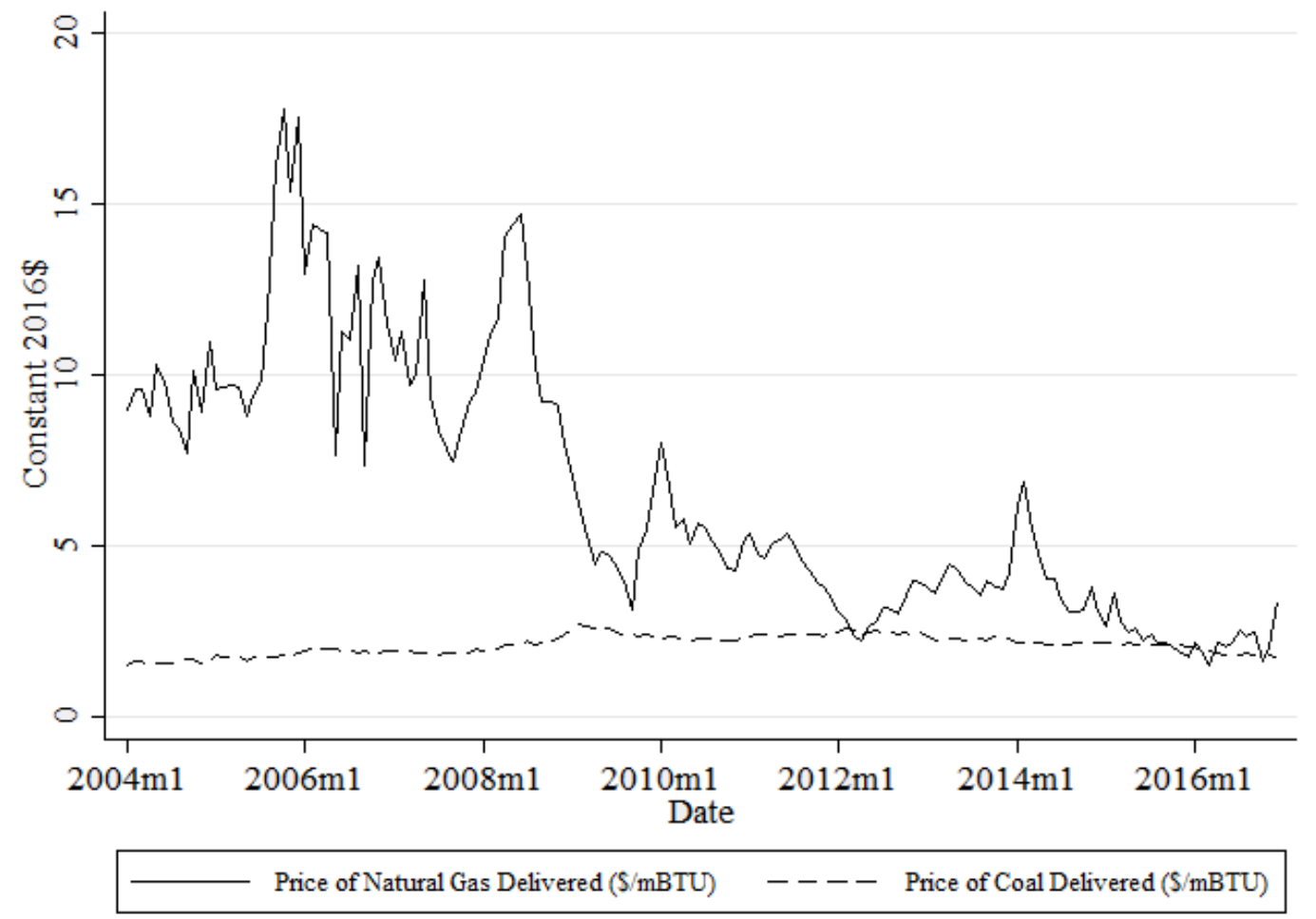

\section{Figure 2. Price of Natural Gas and Coal}

Note: Figure provides the monthly inflation-corrected final marginal price of natural gas and coal ( $\$ / \mathrm{mmBTU})$ delivered to distribution utilities in Ohio between 2004 and 2016. Source: EIA EPM Table 4.10A, 2017.

We note the historic declines in the price of gas that coincide with the U.S. shale production boom beginning in 2008. Hourly wholesale pricing and load data for PJM and MISO, the applicable regional energy markets, is obtained from MarketViews and, for some historical MISO 
load data, from MISO archives. ${ }^{17}$ For consistency across all years of our panel, we do not use PJM's updated residual metered load aggregate technique adopted in June 2015. We convert hourly LMP, inclusive of congestion and losses, to monthly load-weighted average LMP for each utility. This captures price adjusted for load and also reflects diurnal cycles and variability related to weather, forced or unforced generation outages, as well as other regional market conditions. Wholesale data is summarized in Figure 3 for each utility.

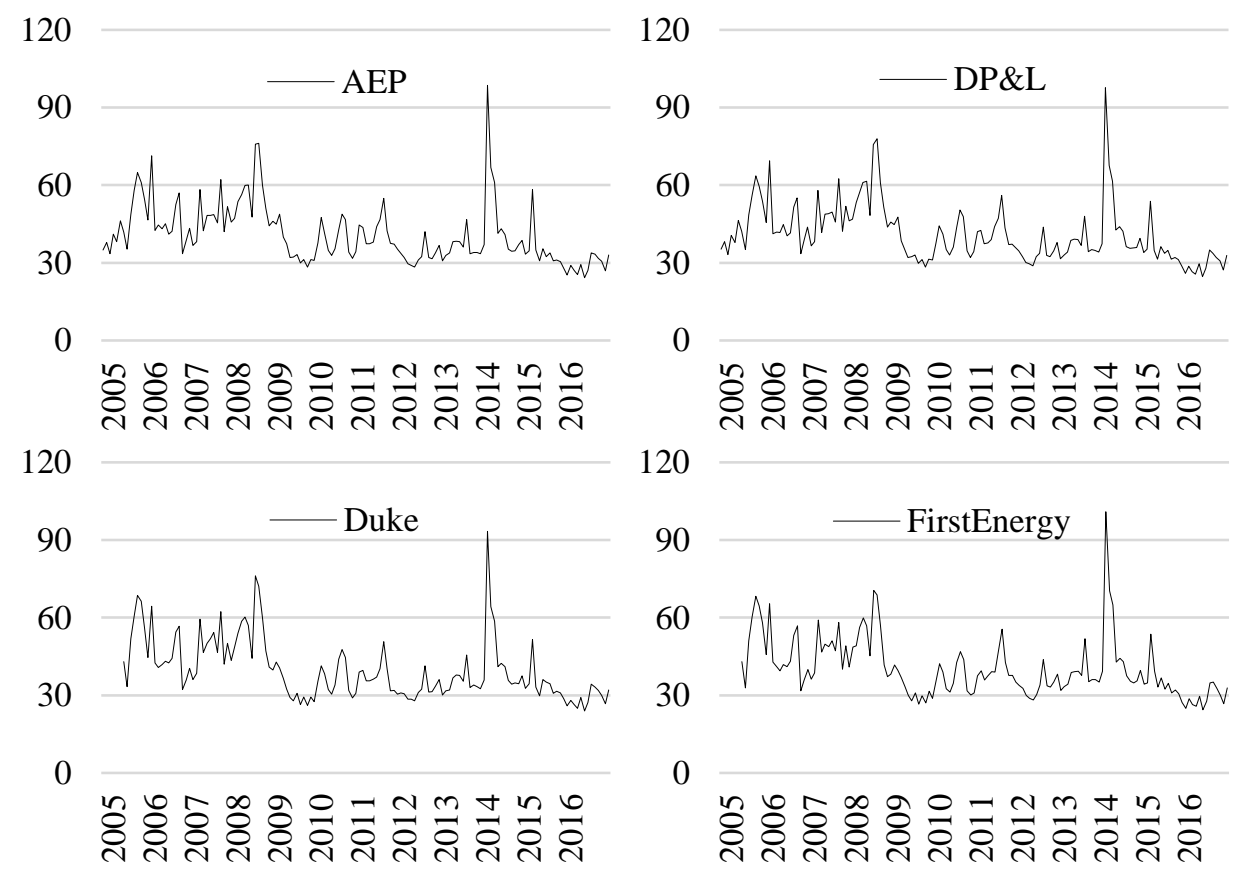

Figure 3: Wholesale Electric Price by Utility Pricing Zone (\$MWh)

Note: Figure provides inflation-corrected monthly load-weighted locational marginal prices (LMPs) for each of the four electric distribution utilities operating in Ohio. Source: PJM, MISO, MarketViews. The spike in January 2014 reflects the Polar Vortex.

We also use key control variables. We obtain total utility operations and maintenance cost data from Federal Energy Regulatory Commission (FERC) Form 1 (comprehensive annual report) and Form 3 (quarterly report) database files. Total operations costs data consists of electricityrelated capital expenditures inclusive of amortization and depreciation, maintenance, labor,

\footnotetext{
${ }^{17}$ See https://www.misoenergy.org/Library/MarketReports/Pages/ArchivedHistoricalRegionalForecastandActualLoad.aspx
} 
regulatory and tax expenditures, and operations. Also obtained from Form 1 and 3 data are dividends declared common and preferred stock, and total sales in MW by customer class. The latter provides an important control for aggregate consumption.

\section{Econometric Approach}

We utilize an econometric estimation approach that is well-suited to our data; long-panels for seven metro areas. We develop estimation models for each customer class as well as price ratio models, described above. Each of the price models estimates marginal retail electric price in inflation-corrected cents/kWh. We utilize the same estimation approach for the inter-class ratio models.

Model selection began with a battery of statistical tests. Following Wooldridge (2010) and Cameron and Trivedi (2005), we utilized a more robust version of the Hausman test under the likely case of a random effects estimator that is not fully efficient. This test also takes into consideration that heteroscedasticity, autocorrelation, and temporal and cross-sectional dependency are typical problems embedded in microeconometric data such as long panels (Hoechle, 2007). The tests strongly suggest that a fixed effects estimation model will provide more consistent estimates. Nonetheless, this version of the Hausman test still considers that neither cross sectional dependence of the errors across units nor within units exists in the data. In order to test for the validity of these assumptions, we performed the Pesaran cross-sectional dependence test. The result implied the presence of cross-sectional dependence of residuals across units (Pesaran, 2004). We also tested for the presence of heteroscedasticity and serial correlation within units, which is common in long panels. Both tests indicated that residuals are not only heteroscedastic but also autocorrelated within units. In this case, it is important to estimate standard errors that 
allow for the modeling of cross sectional dependence, heteroscedasticity, and autocorrelation. Finally, we also performed several tests for unit roots and found that the panels are stationary.

Given these tests, we adopted a model appropriate to these conditions; a linear panel data model that uses a fixed effects, or within regressor, estimator with Driscoll and Kraay (1998) standard errors. The advantage of using a Driscoll-Kraay estimator is that it allows for the application of a Newey-West type correction (Newey and West, 1987), accounting for a general form of autocorrelation in the residuals. This form of autocorrelation is not restricted to an AR(1) process but extends to a more general form, often called spatial correlation, that not only considers serial correlation but correlation across panels. This adjustment is also incorporated into the sequence of cross-sectional averages of the moment conditions, which ensures a consistent estimator of the covariance matrix regardless of the quantity of panels (Hoechle, 2007). The general functional form of our estimation models is given by:

$$
\begin{aligned}
& p_{i t, \tau}=\mathbf{d}_{i, \tau} \delta+\mathbf{z}_{t, \tau}^{g a s} \gamma_{g a s}+\mathbf{d}_{i, \tau} \mathbf{z}_{t, \tau}^{\text {gas }} \zeta_{g a s}+\mathbf{z}_{t, \tau}^{c o a l} \gamma_{c o a l}+\mathbf{W}_{i t, \tau} \omega+\mathbf{C}_{i t, \tau} \varphi+\mathbf{X}_{i t, \tau} \chi+\mathbf{T}_{\tau} \alpha+v_{i}+\varepsilon_{i t, \tau} \\
& p_{i t, \tau}=\mathbf{d}_{i, \tau} \delta+\mathbf{z}_{t, \tau}^{l m p} \gamma_{l m p}+\mathbf{d}_{i, \tau} \mathbf{z}_{t, \tau}^{l m p} \zeta_{l m p}+\mathbf{W}_{i t, \tau} \omega+\mathbf{C}_{i t, \tau} \varphi+\mathbf{X}_{i t, \tau} \chi+\mathbf{T}_{\tau} \alpha+v_{i}+\varepsilon_{i t, \tau}
\end{aligned}
$$

where $p_{i t, \tau}$ is the marginal price per $\mathrm{kWh}$ in metro area $i$ at month $t$ of year $\tau$. Our main explanatory variables are $\mathbf{d}_{i, \tau}$ and $\mathbf{Z}_{t, \tau} . \mathbf{d}_{i, \tau}$ is a binary variable that indicates retail restructuring at month $t$ in year $\tau$. It takes the value of 1 beginning January $2009 .{ }^{18}$ The second set of variables, $\mathbf{Z}_{t, \tau}$ represent the final marginal price of delivered input-fuels. Thus, $\mathbf{Z}_{t, \tau}$ is a vector of input fuel prices for coal and gas, as well as monthly load-weighted wholesale LMP for each distribution utility's pricing zone within their relevant regional transmission organization (RTO) market. Although we have broadly defined the $\mathbf{Z}$ matrix containing input-fuel marginal prices, we have only included gas and

\footnotetext{
${ }^{18}$ The exception is for Dayton which is served by DP\&L. In this case, the dummy takes the value of 1 starting in January 2011.
} 
coal prices in the general form of model 1 (i.e., $\mathbf{z}^{\text {gas }}$ and $\mathbf{z}^{\text {coal }}$ ), on the one hand, and LMP in the general form of model 2 (i.e., $\mathbf{z}^{\mathrm{lmp}}$ ).

We also incorporate vectors associated with additional production side features. $\mathbf{W}_{i t, \tau}$ is a vector representing dividends converted to common and preferred stock for each distribution utility. This controls regulatory-approved price changes associated with corporate protectionism rather than cross-subsidization. The model also includes total operations costs, capital, and labor costs as discussed above, given by vector $\mathbf{C}_{i t, \tau}$. This controls for alternative operational cost-based arguments, such as price changes due to changes in the cost of production inputs (e.g., labor) or the cost of capital. $\mathbf{X}_{i t, \tau}$ is a vector representing electricity sales, in MWh, for a distribution utility and provides a control for monthly demand side effects (e.g., weather, consumption patterns, regional growth). ${ }^{19}$ All models incorporate year fixed effects that help to address annual changes in generation productivity and autonomous energy efficiency improvements (AEEI). These are given by $\mathbf{T}_{\tau}$, in which each binary variable takes the value of 1 for year $\tau$ (from 2004 to 2016) and 0 otherwise. As previously mentioned, our models use the Driscoll-Kraay estimator for the computation of standard errors. These have the following form:

$V(\hat{\theta})=\left(\mathbf{M}^{\prime} \mathbf{M}\right)^{-1} \hat{S}_{T}\left(\mathbf{M}^{\prime} \mathbf{M}\right)^{-1}$,

where $\mathbf{M}$ is a vector of independent variables and $\hat{S}_{T}$ is an estimation of $S_{T}$, the asymptotic covariance matrix. ${ }^{20}$ In this case, $\hat{S}_{T}$ is defined as provided by Newey and West (1987).

\footnotetext{
${ }^{19}$ It is common practice in econometric applications to treat equilibrium prices and quantities as endogenously determined and utilize a simultaneous-equation system for estimation. However, as Ros, (2017, p.78) notes, "when prices are regulated, as is the case in the electricity sector, the relationship between prices and quantities in a simultaneous-equations system may be weaker than in regulated markets and thus perhaps there is less of a need for treating prices and quantities as endogenous." In our case, this is underscored further by the fact that we utilize complete bill data that incorporates the entirety of regulated costs, and by the fact that the marginal price component is based upon fixed average consumption levels by customer class. We supplement this with a full battery of Durbin-Wu-Hausman tests that all fail to reject the null of strict exogeneity.

${ }^{20}$ Readers who are interested in a more detailed explanation should refer to Newey and West (1987), Driscoll and Kraay (1998), and Hoechle (2007).
} 
We also develop price ratio models where $p_{i t, \tau}^{\text {residential }, k}$ represents the ratio of residential prices to comparison class $k$ (either industrial or commercial).

$$
\begin{aligned}
& p_{i t, \tau}^{r e s, k}=\mathbf{d}_{i, \tau} \delta+\mathbf{z}_{t, \tau}^{g a s} \gamma_{g a s}+\mathbf{d}_{i, \tau} \mathbf{z}_{t, \tau}^{\text {gas }} \zeta_{\text {gas }}+\mathbf{z}_{t, \tau}^{c o a l} \gamma_{c o a l}+\mathbf{W}_{i t, \tau} \omega+\mathbf{C}_{i t, \tau} \varphi+\mathbf{X}_{i t, \tau} \chi+\mathbf{T}_{\tau} \alpha+v_{i}+\varepsilon_{i t, \tau} \\
& p_{i t, \tau}^{r e s, k}=\mathbf{d}_{i, \tau} \delta+\mathbf{z}_{t, \tau}^{l m p} \gamma_{l m p}+\mathbf{d}_{i, \tau} \mathbf{z}_{t, \tau}^{l m p} \zeta_{l m p}+\mathbf{W}_{i t, \tau} \omega+\mathbf{C}_{i t, \tau} \varphi+\mathbf{X}_{i t, \tau} \chi+\mathbf{T}_{\tau} \alpha+v_{i}+\varepsilon_{i t, \tau}
\end{aligned}
$$

These take a value equal to 1 when the marginal price ratio between classes is equal. It takes a value greater than 1 when residential customers observe a higher marginal rate, and less than one when residential customers observe a lower marginal rate.

\section{Results}

\subsection{Empirical Tests}

Before introducing the econometric results, we begin with a basic test of Type I crosssubsidization (i.e., inter-class). We conduct Mann-Whitney non-parametric tests of the null hypothesis that the inter-class marginal price ratio is unaffected by retail restructuring. Beginning with this basic test provides a high-level assessment in the absence of additional considerations or statistical controls. The results are provided in Table 3.

Under textbook deregulation, including retail restructuring, we would expect one of two effects on the ratio of prices between customer classes: 1) no change, as would be the case if cost allocation precisely represented cost causation before deregulation with no cross-subsidization; or 2) recalibration of price ratios to reflect market-based cost causation following the introduction of competitive generation pricing via CBP auctions. Almost consistently in each metro area, price ratios increased, reflecting a greater disparity between residential marginal price and industrial and commercial marginal price, respectively. In most cases the null is rejected at the 0.01 level. 
Deviations from this result are observed in Columbus where we see a statisticallysignificant increase in the price ratio for residential to commercial price only. Similarly, in Cleveland we observe a statistically significant increase in the residential to industrial price ratio only. We also observe slight decreases in both ratios in the Dayton metro area. The largest deviation is observed in Canton, where we observe an 8-point decrease in the residential to commercial ratio; though we observe a 9-point increase in the residential to industrial ratio there. The hypothesis test results generally indicate the presence of Type I cross-subsidy, although they do not indicate whether the observed ratio changes are due to the elimination of pre-restructuring Type I subsidies or the creation of new Type I subsidies. To more fully understand these results, we next turn to our econometric models that allow us to control for key explanatory features to further isolate the effects of both Type I and II cross-subsidization.

Table 3. Pre- and Post-Retail Choice Marginal Price Ratios

\begin{tabular}{|c|c|c|c|c|c|c|}
\hline \multirow[b]{2}{*}{$\underline{\text { Metro Area }}$} & \multicolumn{3}{|c|}{$\underline{\text { Residential/Industrial Ratio }}$} & \multicolumn{3}{|c|}{$\underline{\text { Residential/Commercial Ratio }}$} \\
\hline & $\begin{array}{l}\text { Pre-Retail } \\
\text { Choice }\end{array}$ & Retail Choice & $\Delta$ & $\begin{array}{l}\text { Pre-Retail } \\
\text { Choice }\end{array}$ & Retail Choice & $\Delta$ \\
\hline Akron & 1.34 & 1.45 & $0.11 * * *$ & 1.06 & 1.19 & $0.13 * * *$ \\
\hline Canton & 1.50 & 1.59 & $0.09 * *$ & 1.36 & 1.28 & $-0.08 * * *$ \\
\hline Cincinnati & 1.37 & 1.46 & $0.09 * * *$ & 1.18 & 1.21 & $0.03 * *$ \\
\hline Cleveland & 1.10 & 1.35 & $0.25 * * *$ & 1.06 & 1.06 & 0.00 \\
\hline Columbus & 1.87 & 1.88 & 0.01 & 1.16 & 1.23 & $0.07 * * *$ \\
\hline Dayton & 1.51 & 1.48 & $-0.03 * * *$ & 1.36 & 1.35 & $-0.01 * * *$ \\
\hline Toledo & 0.91 & 1.46 & $0.55 * * *$ & 0.96 & 1.12 & $0.16 * * *$ \\
\hline
\end{tabular}

Note: Values indicate the ratio of residential price to the reference class (e.g., 1.5 indicates the marginal price charged to residential customers is $150 \%$ of the industrial or commercial reference group). The delta column reports the difference between pre- and postretail choice marginal price ratios. Asterisks indicate the significance level of Mann-Whitney non-parametric hypothesis tests of the mean equality between the two policy periods by metro area. $\mathrm{n}=1,092 . * * * \mathrm{p}<0.01, * * \mathrm{p}<0.05, * \mathrm{p}<0.1$

\subsection{Econometric Results}

The results of our regression analyses are presented in Tables A1 through A5 in Appendix A; they are too lengthy to include in the main text of the paper. The outcome variable in the models provided in Tables A1 through A3 is the total monthly electric bill marginal price (cents/kWh) for residential, industrial and commercial SSO customers. The outcome variable in the models 
provided in Tables A4 and A5 is the marginal price ratio for residential to industrial, and residential to commercial, respectively.

Each table provides four regression models. Models 1 and 2 use input fuel prices of natural gas and coal delivered as explanatory variables. Models 3 and 4 use the load-weighted LMP. ${ }^{21}$ Models 2 and 4 provide interactive models that decompose our policy intervention (retail restructuring) variable by distribution utility and gas price or wholesale price, respectively. The LMP models provide an interaction variable with our policy intervention dummy for post-retail deregulation to test for Type II cross-subsidization, which would be supported by a negative coefficient on that interaction variable (i.e., declines in the wholesale price associated with increases in retail price). The fuel model does the same with the price of natural gas, which is the key wholesale price driver in both PJM and MISO. ${ }^{22}$ All models provide year fixed effects with the earliest year in our panel, 2004, excluded as the reference case.

We represent the main results of the econometric estimation in Table 4. Here we have included statewide and individual utility-level effects in a way that interprets the coefficients and accounts for interactive effects (i.e., the partial derivatives). The table reports the effects of our cross-subsidization measures as well as the effect of the retail deregulation policy itself. We use the following expressions to compute the restructuring policy change, change due to gas or wholesale price (LMP), and total change, respectively:

Policy effect (fuel models): $\frac{\Delta p}{\Delta d}=p(d=1)-p(d=0)=\delta_{\text {policy }}+\zeta_{\text {gas }} z^{\text {average_gasprice }}$

Gas price effect: $\frac{\partial p}{\partial z} \Delta z=\left(\gamma_{g a s}+\zeta_{g a s} d\right) \times \Delta z$

\footnotetext{
${ }^{21}$ For purposes of econometric estimation in Models 3 and 4, the spike observed in January 2014, due to the Polar Vortex, has been recoded using linear regression-based smoothing.

${ }^{22}$ It is not necessary to provide an interaction term for coal price both because utility-affiliated gencos are almost entirely legacy coal plants and there was no major shift in coal prices (as illustrated in Figure 2 above). In other words, there is no expectation that changes in coal price could affect Type II cross-subsidy.
} 
Policy effect (LMP models): $\frac{\Delta p}{\Delta d}=p(d=1)-p(d=0)=\delta_{\text {policy }}+\zeta_{\text {lmp }} z^{\text {average_lmp }}$

LMP effect: $\frac{\partial p}{\partial z} \Delta z=\left(\gamma_{l m p}+\zeta_{l m p} d\right) \times \Delta z$

Total effect: $\frac{\Delta p}{\Delta d}+\frac{\partial p}{\partial z} \Delta z$

For simplification, we have avoided some sub-indexes but have kept the same notation for parameters and variables representing the policy dummy, gas prices, and LMP included in equations 1 through 5 .

The effects reported in Table 4 are based on a panel average natural gas price of \$3.9/mmBTU and LMP of \$37.3/MWh. Gas price and LMP effects, our metrics for Type II crosssubsidization, are based on the observed decrease $(\Delta \mathrm{z})$ of approximately $\$ 6.5 / \mathrm{mmBTU}$ in the natural gas price and $\$ 30 / \mathrm{MWh}$ in the wholesale price, respectively. Importantly, negative commodity price coefficients in Tables A1 through A5 reflect unfavorable effects from the standpoint of households and businesses; they indicate that with decreasing gas or wholesale electricity prices, retail electric prices increased. For ease of exposition, we have interpreted the results shown in Table 4 in terms of the effect observed by consumers.

We would expect that, following adoption of a market-based pricing construct, decreases in both the marginal fuel source (natural gas) price and the wholesale market price would be passed on to businesses and households as savings. Noting that positive values in Table 4 indicate increases in retail rates (except for the price ratio models), we observe that all customers in Ohio (with the exception of Duke- the only utility that functionally divested its legacy coal fleet) observed increases in the marginal price of electricity in response to the historic declines in both the gas and wholesale price. We next interpret these results in greater detail. 
Table 4. Main Econometric Results Interpreted

\begin{tabular}{|c|c|c|c|c|c|c|c|}
\hline \multirow[b]{2}{*}{ Utility } & \multirow[b]{2}{*}{ Model } & \multirow[b]{2}{*}{ Effect } & \multicolumn{3}{|c|}{ Price Models } & \multicolumn{2}{|c|}{ Price Ratio Models } \\
\hline & & & Residential & Industrial & Commercial & Res/Ind Ratio & Res/Comm Ratio \\
\hline \multirow{6}{*}{$\begin{array}{c}\text { Statewide } \\
\text { Effects }\end{array}$} & \multirow{3}{*}{ Model 1} & Gas Price & 1.888 & -- & 2.022 & -- & -- \\
\hline & & Policy & 0.214 & -- & 0.656 & -- & -0.062 \\
\hline & & Total & 2.103 & -- & 2.678 & -- & -0.062 \\
\hline & \multirow{3}{*}{ Model 3} & $L M P$ & 0.912 & -- & 0.895 & -0.031 & -0.017 \\
\hline & & Policy & 0.004 & -- & 0.426 & -- & -0.036 \\
\hline & & Total & 0.915 & -- & 1.321 & -0.031 & -0.054 \\
\hline \multirow{6}{*}{$\begin{array}{c}\mathrm{FE}^{\dagger} \\
\text { (Corporate } \\
\text { separation) }\end{array}$} & \multirow{3}{*}{ Model 2} & Gas Price & 0.519 & -- & 0.383 & -- & -- \\
\hline & & Policy & -2.241 & -3.596 & -1.828 & -- & -- \\
\hline & & Total & -1.722 & -3.596 & -1.446 & -- & -- \\
\hline & \multirow{3}{*}{ Model 4} & $L M P$ & 1.044 & -0.047 & 0.965 & -- & -0.021 \\
\hline & & Policy & -1.952 & -2.804 & -1.948 & 0.236 & -- \\
\hline & & Total & -0.908 & -2.851 & -0.984 & 0.236 & -0.021 \\
\hline \multirow{6}{*}{$\begin{array}{c}\text { AEP } \\
\text { (Corporate } \\
\text { separation) }\end{array}$} & \multirow{3}{*}{ Model 2} & Gas Price & 4.324 & 3.220 & 4.186 & -- & -- \\
\hline & & Policy & 1.321 & 1.290 & 1.882 & -- & -- \\
\hline & & Total & 5.645 & 4.510 & 6.068 & -- & -- \\
\hline & \multirow{3}{*}{ Model 4} & $L M P$ & 1.444 & 1.215 & 1.474 & -- & -- \\
\hline & & Policy & 0.718 & 1.116 & 1.451 & -- & -- \\
\hline & & Total & 2.162 & 2.330 & 2.925 & -- & -- \\
\hline \multirow{6}{*}{$\begin{array}{c}\text { Duke }^{\ddagger} \\
\text { (Functional } \\
\text { separation) }\end{array}$} & \multirow{3}{*}{ Model 2} & Gas Price & -2.041 & -2.473 & -1.907 & 0.148 & -- \\
\hline & & Policy & -0.985 & -0.709 & 0.080 & -0.003 & -- \\
\hline & & Total & -3.026 & -3.182 & -1.827 & 0.145 & -- \\
\hline & \multirow{3}{*}{ Model 4} & $L M P$ & -- & -0.555 & -0.509 & 0.089 & 0.060 \\
\hline & & Policy & -- & -0.734 & -0.260 & -0.049 & -0.058 \\
\hline & & Total & -- & -1.289 & -0.770 & 0.040 & 0.003 \\
\hline \multirow{6}{*}{$\begin{array}{c}\text { DPL } \\
\text { (Corporate } \\
\text { separation) }\end{array}$} & \multirow{3}{*}{ Model 2} & Gas Price & 0.335 & -- & 0.284 & -0.139 & -0.077 \\
\hline & & Policy & -- & -- & -- & -0.148 & -0.054 \\
\hline & & Total & 0.335 & -- & 0.284 & -0.287 & -0.131 \\
\hline & \multirow{3}{*}{ Model 4} & $L M P$ & 0.331 & -- & 0.356 & -0.059 & -- \\
\hline & & Policy & -- & -- & -- & -0.163 & -0.082 \\
\hline & & Total & 0.331 & -- & 0.356 & -0.222 & -0.082 \\
\hline
\end{tabular}

Note: Cells identified with dashes represent statistically nonsignificant effects at the 10 percent level. The effects are based on a panel average natural gas price of $\$ 3.9 / \mathrm{mmBTU}$ and LMP of $\$ 37.3 / \mathrm{MWh}$. Gas price and LMP effects are based on the observed decrease $(\Delta \mathrm{z})$ of $\$ 6.5 / \mathrm{mmBTU}$ in the natural gas price and $\$ 30 / \mathrm{MWh}$ in the wholesale price, respectively.

${ }^{\dagger}$ Both coal and nuclear assets owned by arms-length genco. $¥$ Utility has divested generation assets. 


\subsubsection{Type I (Inter-class) Cross-Subsidization Results}

The results of the ratio models indicate that retail deregulation generally had small and nonsignificant effects on the disparity in electric rates between residential and commercial or industrial customers, respectively. In Table 4, we observe very slight but statistically significant decreases of between .036 and .062 in the residential to commercial ratio on a statewide basis. We note that many of the ratio model coefficients are not statistically significant, however, and are thus not incorporated into the total effect in Table 4 . This result is driven predominantly by reductions in the DP\&L and Duke territory residential to commercial ratios. The lack of statistical significance in the statewide residential to industrial ratio is also due to disparate results in the DP\&L and FirstEnergy territories; we observe a statistically significant ratio increase for FirstEnergy in Model 4, but also a statistically significant decrease for DP\&L in Models 2 and 4. There is also a slight decreasing effect for Duke in Models 2 and 4. Thus, the lack of an aggregate impact on the largest relative price disparity, the residential to industrial ratio, stems from countervailing effects of retail deregulation in three relevant service territories. We next turn to evaluations of the price regressions to understand these effects further.

In all cases and for all customer classes, we observe positive coefficients for the statewide policy effect of retail deregulation, as provided in Tables A1 through A3 for Models 1 and 3. However, as our models include interaction terms between the policy dummy and the gas price variable, we also consider this term when calculating the statewide effect (as indicated in equations 6 through 10). The results indicate that there has been an overall increase in electric rates for all customer classes. However, we observe statistically significant increases in these models only for residential and commercial customers. These overall results provide some evidence of Type I cross-subsidization in so far as there are disparities in how the market-basis for cost-allocation 
affects relative prices. In other words, relative prices do not appear to change in the same direction (e.g., increase or decrease in relation to broader market factors) or in relation to each other (e.g., rates for one class experience inverse changes in relation to another when a previous cross-subsidy is eliminated). Instead, restructuring appears to favor the industrial class, which is the only customer class to not observe significant rate increases associated with retail deregulation.

Decomposing these effects by utility, as provided in Models 2 and 4, we can examine individual utility effects of retail restructuring. We observe statistically significant decreases in residential rates in the FirstEnergy and Duke territories. The statewide effect, however, is mitigated by the substantial increase in residential rates in the AEP service territory. Similarly, we observe statistically significant commercial customer savings in Model 2 for FirstEnergy, but also mitigating price increases for AEP.

Comparing those results with the industrial price results is most indicative of increased Type I cross-subsidization. The general results indicate that, where prices decreased with retail deregulation, the greatest savings were allocated to industrial customers. We observe statistically significant industrial rate decreases in the FirstEnergy and Duke territories that are larger than similar changes in residential and commercial prices. Additionally, where prices increased with retail deregulation, they increased the least for industrial customers. Industrial prices, like residential and commercial prices, increase in the AEP territory, although at a lower magnitude. In other words, industrial customers observe greater gains to the gainers, but fewer losses to the losers.

It is instructive that the effect of retail deregulation is disparate across customer class. The mechanism for setting the generation component of SSO customer bills (i.e., the deregulated component of bills) is the CBP auction, which results in a single generation price for all three 
customer classes. Moving to a single generation price should, all things equal, tend to harmonize price across customer classes. An alternative explanation for this result, as mentioned above, is that moving to a single generation price served to eliminate a pre-existing cross subsidy. An increased ratio is plausible if households were benefitting from cross-subsidization before restructuring. While we cannot rule this out completely, we can obtain further insight relating to Type I cross-subsidy by looking at inter-class differences in the allocation of inter-firm (Type II) cross-subsidy, which we turn to next.

\subsubsection{Type II (Production Side) Cross-Subsidization}

We next evaluate production side, Type II cross-subsidization, or inter-firm. With the precipitous decline in natural gas price associated with the shale boom, Ohio has observed significant declines in both the delivered price of natural gas and the load-weighted wholesale LMP. ${ }^{23}$ It has similarly observed a substantial buildup of the natural gas fleet (Dormady, 2017). ${ }^{24}$ This has placed utility-affiliated gencos in a precarious position as they are almost entirely coalfired.

The regression results provide strong evidence that the favorable decrease in natural gas prices has tended to have an upward (unfavorable) effect on retail electric prices, with the exception of the only utility that functionally divested its generation assets - discussed below. Both Models 1 and 2 provide regression results of input fuel prices for coal and gas as delivered to Ohio

\footnotetext{
${ }^{23}$ The most common production resource to set the LMP, particularly in the PJM RTO, is natural gas. Thus, gas tends to be the marginal resource in the dispatch merit order that most commonly sets the auction-clearing price in the day-ahead and real-time markets.

${ }^{24}$ Ohio has observed a monotonically-increasing natural gas generation fleet, predominantly from non-utility-affiliated wholesale generation. Between 2004 and 2016, the first and last years of the panel utilized for this analysis, the gas component of the fuel fleet has increased from 0.01 percent to 31.7 percent. There is currently approximately 3,000 MW of planned construction in Ohio by the year 2020 (see EIA's Electric Power Monthly Table 6.5, available at http://www.eia.gov/electricity/monthly/). According to PJM, 6,740 MW of capacity was deactivated in Ohio in 2015 and several additional unit retirement requests are pending currently (see http://www.pjm.com/planning/generation-deactivation/gd-summaries.aspx). These are predominantly coal-fired units.
} 
utilities. Model 1 provides the aggregate statewide marginal effect of gas price, and its interaction with the deregulation policy dummy provides the aggregate post-deregulation marginal effect. Model 2 decomposes the effects by utility. We note that the monthly average price of natural gas delivered to electric generation units in Ohio decreased from over $\$ 10 / \mathrm{mmBTU}$ before retail deregulation, to approximately $\$ 3 / \mathrm{mmBTU}$ by December 2016 . We thus adopt a difference of $\$ 6.5 / \mathrm{mmBTU}$ for the purpose of interpreting coefficients in Table 4.

We observe an average statewide increase in residential prices that is indicative of Type II cross-subsidization. The results suggest that a $\$ 6.5 / \mathrm{mmBTU}$ decrease in the price of gas during the analyzed period has had an overall effect of increasing residential electric rates by approximately 1.888 cents/kWh. That exceeds a 500 percent increase as compared with the prederegulation effect of .305 cents $/ \mathrm{kWh}$. In a deregulated market that has moved toward a more market-based pricing construct for retail power, substantial decreases in the price of a key input fuel, like natural gas, should translate in some way to savings to retail customers. Ohio customers have observed the opposite effect, however. The decreases in gas price also resulted in losses to arms-length, utility-affiliated coal generation. The data indicates that those losses have been crosssubsidized by the regulated component of retail electric bills. We also observe similar effects for commercial rates, with an overall increase of 2.022 cents $/ \mathrm{kWh}$ during the post-deregulation period.

It is noteworthy that, in terms of magnitude, the deleterious effects of Type II crosssubsidization tend to lessen and, in some cases, negate any favorable effects of retail deregulation. For example, in the retail price regression models, the net effect of retail deregulation has been a slight increase in price of .214 cents/kWh. The total effect, however, swells to a 2.103 cents/kWh increase in the rate paid by residential customers when accounting for the Type II cross-subsidy. 
Evaluating the results of Model 2 allows us to decompose these effects by utility. For all customers except Duke (discussed below), we observe unfavorable Type II effects. This is most unfavorable for AEP customers, who observe a 5.645 cents/kWh increase in rates with the implementation of retail restructuring. In the case of FirstEnergy, although the Type II crosssubsidy reduced the favorable impact of retail restructuring, the total effect during the postderegulation period is still favorable to residential customers, -1.722 cents/kWh. In the DP\&L territory, we observe an unfavorable effect to residential customers, increased rates by .335 cents/kWh after retail restructuring.

The wholesale price models (Models 3 and 4) provide further insights. In the absence of Type II effects, we would expect decreases in the wholesale price to correspond with decreases in the retail price of electricity, particularly when the CBP auction that sets SSO rates closely tracks the wholesale price. However, in the presence of Type II effects, we expect an inverse relationship-decreases in the wholesale price correspond with reductions in generation revenue that incentivize cross-subsidization by regulatory cost recovery.

The results of Model 3 directly comport with Type II effects. Prior to retail deregulation the mean LMP was $\$ 55 / \mathrm{MWh}$, and by the end of the analyzed period, it had fallen to approximately $\$ 25 / \mathrm{MWh}$. This $\$ 30 / \mathrm{MWh}$ decrease in the wholesale price of electricity is associated with an average increase of .912 cents $/ \mathrm{kWh}$ in residential retail rates and a .895 cents $/ \mathrm{kWh}$ increase in commercial retail rates. We do not observe statistically significant aggregate effects for industrial rates - providing some additional evidence of Type I cross-subsidization.

Decomposing the wholesale model results by utility, as provided in Model 4, confirms the statewide finding. The effects are unfavorable and statistically significant for AEP and FirstEnergy, indicating that customers have observed higher retail rates associated with decreases 
in the wholesale price. A $\$ 30$ wholesale price decrease is associated with a residential price increase of 1.044 and 1.444 cents/kWh for FirstEnergy and AEP, respectively. For commercial rates, the increase is .965 cents/kWh and 1.474 cents/kWh, respectively. This adverse Type II effect essentially diminishes most, or all, of any favorable effects of retail choice.

Summarizing these results concisely, where retail deregulation has benefited customers on the deregulated component of their bills, the favorable effects have been cancelled out by corresponding increases in the regulated component (i.e., riders). And, where retail deregulation has had a detrimental effect on the deregulated component of customers' bills, those adverse effects have been compounded by corresponding increases in the regulated component.

\subsubsection{Functional Versus Corporate Separation}

Why are the results so strikingly different for Duke Energy (Cincinnati metro area)? Duke is the only distribution utility in Ohio that has functionally divested, rather than corporately separated, nearly all of its generation assets. ${ }^{25}$ Duke does not maintain a large legacy coal fleet on an arms-length balance sheet, and thus does not have the same need to seek cost recovery to crosssubsidize the losses of a legacy coal fleet in an era of low gas price. Other distribution utilities in the state have only corporately separated their legacy coal fleets - as permitted by the PUCO. For them, losses of utility-affiliated generation show up on the distribution utility's parent company's balance sheets. This creates a perverse cost recovery incentive that ultimately contributes to the

\footnotetext{
${ }^{25}$ This does not include Duke's Ohio Valley Electric Corporation (OVEC) entitlement. Duke, along with seven other utilities in both regulated and deregulated markets, owns a small share of the OVEC. OVEC is a cooperative that maintains and operates two legacy coal plants which, historically, provided service to a Department of Energy (DOE) managed uranium enrichment plant. DOE's agreement with OVEC will end by 2023, and most power requirements already ended in 2003. An inter-company power agreement between the sponsoring utilities, however, will run through 2040. As a result, Duke is responsible for nine percent of OVEC's power market costs and benefits, equivalent to ownership of approximately $215 \mathrm{MW}$ of coal generation. Prior to divestiture, this amounted to less than four percent of Duke's Ohio generation business. Duke, to-date, has had minimal involvement in discussions regarding OVEC subsidization. This will likely change if other utilities successfully receive economic support for their share of OVEC.
} 
inverse relationship between fuel or LMP price and retail price that appears so robustly in the econometric models. Duke, which completed a lengthy divestiture process by 2014 , does not have the same perverse cost recovery motivation.

For Duke, the results indicate net savings associated with retail deregulation of approximately 3.026 cents/kWh for residential, 3.182 cents/kWh for industrial, and 1.827 cents $/ \mathrm{kWh}$ for commercial customers, associated with the observed decrease of $\$ 6.5 / \mathrm{mmBTU}$ in the price of gas. Thus, our results would tend to support the conclusion that retail deregulation, if accompanied by appropriate divestiture, can mitigate the incentive to seek Type II crosssubsidization. This is consistent with Morey and Kirsch (2016), who argue that the favorable benefits of retail restructuring can be adversely impacted by incomplete functional separation. It is also noteworthy that for Duke we still observe proportionately larger savings for industrial customers. This suggests that while adequate divestiture may improve Type II cross-subsidization, it does not necessarily improve Type I.

\section{Implications \& Conclusions}

Prior assessments of retail electric restructuring are opaque with respect to inequalities in cost. These studies generally rely on EIA data that does not account for customer-funded passthroughs associated with holding company structures. Prior U.S. research also generally adopts multi-state assessments that overlook important state- and utility-level dynamics, such as divestiture status, operational details, and other retail market dynamics. Few undertake an empirical analysis of relative changes in cross-subsidization.

This paper provides a monthly panel analysis between 2004 and 2016 of the effect of Ohio's implementation of retail restructuring on residential, commercial, and industrial complete 
bills. The results provide evidence that retail restructuring led to two types of cross-subsidization. First, the findings suggest that, where customers observed savings associated with retail choice, the greatest savings have been observed by industrial customers and, where customers have observed cost increases, the greatest increases have been observed by households (Type I crosssubsidization). Second, the findings suggest that, while customers have generally observed some savings associated with the implementation of the competition construct (i.e., the deregulated component of their bill), savings have generally been more than offset by cross-subsidies to utilityaffiliated gencos (Type II cross-subsidization). Two robust measures of this effect, using either the load-weighted wholesale LMP or the delivered price of natural gas, provide strong evidence that increases in customer bills following restructuring occurred in response to losses observed by deregulated utility affiliate firms.

It is noteworthy that Ohio provides a unique natural experiment—-this effect occurred in almost exactly the opposite direction and magnitude for the only utility in the state that functionally divested essentially the entirety of its generation, Duke Energy (Cincinnati metro area). Customers in the Duke service territory observed net savings associated with historic declines in the price of natural gas after retail restructuring. Decreases in natural gas price and associated declines in wholesale market prices are consistently associated with increasing electricity prices in other service territories where utilities only corporately separated. Existing literature suggests that restructuring should allow retail rates to reflect wholesale rates and the price of the marginal fuel resource, typically natural gas. While enabling legislation required 100 percent divestiture of generation assets, utilities were permitted to corporately rather than functionally divest those assets. By selling those generation assets (almost entirely legacy coal plants) to deregulated armslength companies, they created a perverse cost recovery incentive. When those coal assets 
performed poorly in the shale boom era, utilities sought riders through their regulated distribution businesses to compensate for losses of their deregulated generation businesses. The largest share of this burden was passed to households.

The classical model for electric deregulation includes unbundling of generation from regulated utility functions in order to remove the temptation for regulated utilities to preferentially exercise their monopoly power to cross-subsidize their deregulated generation businesses. Absent protection against this behavior, scholars predicted behavior that would crowd out competition (Joskow and Schmalensee, 1983). Our results provide some evidence to suggest that corporate separation is insufficient to remove important cross-subsidy incentives. It is interesting to note that Hartley, Medlock, and Jankovska's (2017) work, which also uses total bill data but focuses on Texas, finds evidence of changes in cross-subsidy that benefit residential customers. Notably, Texas enforced strict, full divestiture of generation assets and therefore promotes pass-through of market costs to retail customers. Replication studies examining similar total bill data in other restructured geographies, coupled with in-depth examination of policy implementation and design, could further corroborate these findings regarding divestiture.

This paper also provides insights about both Ohio's restructuring and the risks of imperfect retail restructuring more broadly. Ohio's retail restructuring law (SB 221) allowed mechanisms for utilities to seek additional cost-recovery in the form of non-bypassable riders and surcharges. Further compounding the issue, the ESP process in Ohio does not obligate the same procedural checks-and-balances as traditional cost-of-service regulation. In essence, Ohio created a competitive ratemaking mechanism but retained single-issue ratemaking, just as many other states retained elements of regulated ratemaking. As Joskow (2008) and others note, incomplete or imperfect market reform is the status quo in most states and countries that adopted retail 
restructuring. The presence of residual regulatory interference appears to undermine the potential benefits of competition. Regulators and legislators interested in understanding the differential effects of retail restructuring might, therefore, be better served looking inwards - at political and regulatory processes that affect these markets - before adjudicating the theory of deregulation. Similarly, researchers might finally settle the ambiguity about the impact of electric deregulation with better specification of the additional, non-market determinants of deregulation outcomes.

Likewise, these findings have potentially significant implications for the efficiency of wholesale markets. Regulatory subsidization of generation units can have both short run and long run adverse efficiency consequences for wholesale markets (Dormady, 2017). These consequences would be borne out in the short run if Type II cross-subsidization allows utility-affiliated gencos to displace more efficient generation units in the unit commitment process. And, these consequences would be borne out in the long run if cross-subsidization delays efficient retirement decisions and discourages market entry by more efficient units.

We acknowledge that there may be important societal benefits, including economic development rationales, that would justify inter-class cross-subsidization. In other words, the exact ratio of cross-subsidization from households to job creators is a political and normative exercise rather than an empirical one. Here we simply report the results of our analyses that provide evidence that relative prices changed in important ways with the implementation of retail restructuring rather than by an elected legislature. Given that Ohio's post-restructuring competition construct is a CBP procurement auction that results in a single price to all three SSO customer classes, these results run counter to expectations that a single price would tend to harmonize interclass differentials. They do, however, confirm Borenstein and Bushnell's (2015) argument that an underlying motivation for reform was always rent shifting. That is, residential customer's share of 
costs appears to increase after restructuring. Additionally, the results suggest that regulators approved riders and surcharges that were used to cross-subsidize deregulated generation, and they were disproportionately added to residential customers' bills. This counters the narrative that restructuring eliminated Type I cross-subsidy.

We also note that Type I cross-subsidization is not generally an unexpected outcome of atleast partially regulated industries. Since Mancur Olson's (1965) seminal work on collective action, we have understood that oftentimes deliberative agency processes result in diffuse costs and concentrated benefits. Allowing differentials in cost across customer class to result from formalized rate-setting processes creates an incentive for rent seeking that puts diffuse interests, such as households, at a potential disadvantage relative to industrial interest groups in commission proceedings. A promise of restructuring was supposedly the leveling of this playing field through markets. 


\section{References}

Apt, J. (2005). Competition has not lowered US industrial electricity prices. The Electricity Journal, 18(2), 52-61.

Averch, H. and Johnson, L. L. (1962). Behavior of the firm under regulatory constraint. The American Economic Review, 52(5), 1052-1069.

Borenstein, S. and Bushnell, J. B. (2015). The U.S. electricity industry after 20 years of restructuring (EI @ Haas Working Paper No.252R). Berkeley, CA: Energy Institute at Haas.

Bushnell, J., Mansur, E. T. and Novan, K. (2017). Review of the economics literature on US electricity restructuring. Unpublished manuscript, Department of Economics, University of California at Davis, Davis, CA.

Bushnell, J., Mansur, E. T. and Saravia, C. (2008). Vertical arrangements, market structure, and competition: An analysis of restructured US electricity markets. American Economic Review, 98(1), 237-266.

Cameron, A. C. and Trivedi, P. K. (2005). Microeconometrics: methods and applications. New York, NY: Cambridge University Press.

Chao, H. P. and Huntington, H. G. (Eds.). (1998). Designing competitive electricity markets. Boston, MA: Kluwer Academic.

Defeuilley, C. (2009). Retail competition in electricity markets. Energy Policy, 37(2), 377-386.

Dormady, N. (2017). Having your cake and eating it too: Ohio's proposals to re-regulate through power purchase agreements. The Electricity Journal, 30(5), 42-46.

Dormady, N., Jiang, Z. and Hoyt, M. (2018). Do markets make good commissioners?: A quasiexperimental analysis of retail electric restructuring in Ohio. Journal of Public Policy, Forthcoming.

Driscoll, J. C. and Kraay, A. C. (1998). Consistent covariance matrix estimation with spatially dependent panel data. The Review of Economics and Statistics, 80(4), 549-560.

Erdogdu, E. (2011). The impact of power market reforms on electricity price-cost margins and cross-subsidy levels: A cross country panel data analysis. Energy Policy, 39(3), 1080-1092.

Eto, J. H., Hale, D. R. and Lesieutre, B. C. (2006). Toward more comprehensive assessments of FERC electricity restructuring policies: A review of recent benefit-cost studies of RTOs. The Electricity Journal, 19(10), 50-62. 
Hartley, P. R., Medlock, K. B., III, and Jankovska, O. (2017). Electricity reform and retail pricing in Texas. Unpublished manuscript, Center for Energy Studies, Baker Institute for Public Policy, Rice University, Houston, TX.

Hoechle, D. (2007). Robust standard errors for panel regressions with cross-sectional dependence. Stata Journal, 7(3), 281-312.

Hunt, S. (2002). Making competition work in electricity. New York, NY: John Wiley \& Sons.

Ishii, J. and Yan, J. (2007). Does divestiture crowd out new investment? The "make or buy" decision in the US electricity generation industry. The RAND Journal of Economics, 38(1), $185-213$.

Joskow, P. L. (1989). Regulatory failure, regulatory reform, and structural change in the electric power industry. Brookings Papers on Economic Activity: Microeconomics, 125-199.

Joskow, P. L. (1998). Electricity sectors in transition. The Energy Journal, 19(2), 25-52.

Joskow, P. L. (2000). Why do we need electricity retailers? Or can you get it cheaper wholesale? Unpublished manuscript, Department of Economics, Massachusetts Institute of Technology, Boston, MA.

Joskow, P. L. (2006). Markets for power in the United States: An interim assessment. The Energy Journal, 27(1), 1-36.

Joskow, P. L. (2008). Lessons learned from electricity market liberalization. The Energy Journal, 29(2), 9-42.

Joskow, P. L. \& Schmalensee, R. (1983). Markets for power: An analysis of electric utility deregulation. Cambridge, MA: MIT Press.

Kwoka, J. (2008). Restructuring the US electric power sector: A review of recent studies. Review of Industrial Organization, 32(3-4), 165-196.

Kwoka, J., Pollitt, M. and Sergici, S. (2010). Divestiture policy and operating efficiency in US electric power distribution. Journal of Regulatory Economics, 38(1), 86-109.

Littlechild, S. (2000). Why we need electricity retailers: A reply to Joskow on wholesale spot price pass-through (DAE Working Paper No. 0008). Cambridge, United Kingdom: Department of Applied Economics, University of Cambridge.

Littlechild, S. (2002). Competition in retail electricity supply. Journal des conomistes et des tudes Humaines, 12(2).

Littlechild, S. (2008). Municipal aggregation and retail competition in the Ohio energy sector. Journal of Regulatory Economics, 34(2), 164-194. 
Mansur, E. T. (2007). Upstream competition and vertical integration in electricity markets. The Journal of Law and Economics, 50(1), 125-156.

McKearin, T.K. (2015). "Essays on the effects of government intervention in Texas' electricity market and the health insurance markets in Missouri and Oklahoma." Doctoral Dissertation, Department of Economics, University of Texas at Austin, Austin, TX.

Morey, M.J. and Kirsch, L.D. (2016). "Retail choice in electricity: What have we learned in 20 years?" Christensen Associates Energy Consulting, retrieved June 29, 2018 from https://sites.hks.harvard.edu/hepg/Papers/2016/Retail\%20Choice\%20in\%20Electricity\%2 0for\%20EMRF\%20Final.pdf.

Nagayama, H. (2007, February). Effects of regulatory reforms in the electricity supply industry on electricity prices in developing countries. Energy Policy, 35, 3440-3462.

Newey, W. K. and West. K. D. (1987). A simple, positive semi-definite, heteroskedasticity and autocorrelation consistent covariance matrix. Econometrica, 55, 703-708.

Olson, M. (1965). The logic of collective action. Cambridge, MA: Harvard University Press.

Peltzman, S. (1976). Toward a more general theory of regulation (NBER Working Paper No. 133). Cambridge, MA: National Bureau of Economic Research.

Public Utility Commission of Ohio (PUCO) (2018) AEP Ohio's electric security plan IV. Retrieved July 6, 2018 from: https://www.puco.ohio.gov/be-informed/consumertopics/aep-ohios-electric-security-plan-iv/.

Menezes, R. and Penn, I. (2017). Californians are paying billions for power they don't need. Los Angeles Times. Retrieved July 6, 2018 from: http://www.latimes.com/projects/la-fielectricity-capacity/.

Pesaran, M. H. (2004, August). General diagnostic tests for cross section dependence in panels (CESifo Working Paper No. 1229). Munich, Germany: Center for Economic Studies \& Ifo Institute for Economic Research.

Phillips, C. F. (1993). The regulation of public utilities: Theory and practice. Arlington, VA: Public Utilities Reports.

Posner, R. A. (1974, Autumn). Theories of economic regulation. The Bell Journal of Economics and Management Science, 5(2), 335-358.

Ros, A. J. (2017). An econometric assessment of electricity demand in the United States using utility-specific panel data and the impact of retail competition on prices. The Energy Journal, 38(4), 73-99. 
Stigler, G. J. and Friedland, C. (1962). What can regulators regulate? The case of electricity. Journal of Law \& Economics, 5, 1-16.

$\mathrm{Su}, \mathrm{X}$. (2015). Have customers benefitted from electric retail competition? Journal of Regulatory Economics, 42(2), 146-182.

Swadley, A. and Yücel, M. (2011). Did residential electricity rates fall after retail competition? A dynamic panel analysis. Energy Policy, 39(12), 7702-7711.

Tsai, C.-H and Tsai, Y.-L. (2018). "Competitive retail electricity market under continuous price regulation." Energy Policy 114(12), 274-287.

Thomas, A. R., Lendel, I. and Park, S. (2014). Electricity markets in Ohio. Unpublished manuscript, Maxine Goodman Levin College of Urban Affairs, Cleveland State University, Cleveland, $\mathrm{OH}$.

Whitworth, D. and Zarnikau, J. (2006). Has electric utility restructuring led to lower electricity prices for residential consumers in Texas? Energy Policy, 34(15), 2191-2200.

Winston, C. (1993, September). Economic deregulation: Days of reckoning for microeconomists. Journal of Economic Literature, 31(3), 1263-1289.

Woo, C. K. and Zarnikau, J. (2009). Will electricity market reform likely reduce retail rates? The Electricity Journal, 22(2), 40-45.

Wooldridge, J. M. (2010). Econometric analysis of cross section and panel data. Cambridge, MA: MIT Press. 


\section{Appendix A. Regression Tables}

Table A1. Regression Analysis of Retail Price (Residential Bills)

\begin{tabular}{|c|c|c|c|c|}
\hline RESIDENTIAL MARGINAL PRICE & $\begin{array}{c}(1) \\
\text { XTSCC } \\
\end{array}$ & $\begin{array}{c}(2) \\
\text { XTSCC-I } \\
\end{array}$ & $\begin{array}{c}(3) \\
\text { XTSCC } \\
\end{array}$ & $\begin{array}{c}(4) \\
\text { XTSCC-I } \\
\end{array}$ \\
\hline Deregulation & $\begin{array}{c}1.159 \\
(0.601)\end{array}$ & & $\begin{array}{c}1.095 * \\
(0.519)\end{array}$ & \\
\hline Deregulation_FirstEnergy & & $\begin{array}{l}-2.241 * * \\
(0.694)\end{array}$ & & $\begin{array}{c}0.1681 \\
(0.762)\end{array}$ \\
\hline Deregulation_AEP & & $\begin{array}{l}3.774 * * * \\
(0.806)\end{array}$ & & $\begin{array}{l}2.472 * * \\
(0.775)\end{array}$ \\
\hline Deregulation_Duke & & $\begin{array}{l}-2.303^{*} \\
(0.986)\end{array}$ & & $\begin{array}{l}-2.281 \\
(1.233)\end{array}$ \\
\hline Deregulation_DP\&L & & $\begin{array}{l}-0.559 \\
(0.968)\end{array}$ & & $\begin{array}{l}-0.481 \\
(1.015)\end{array}$ \\
\hline NatGasDeliv_Price & $\begin{array}{l}-0.0467 * \\
(0.0201)\end{array}$ & & & \\
\hline GasPrice_FirstEnergy & & $\begin{array}{l}-0.0794 * \\
(0.0349)\end{array}$ & & \\
\hline GasPrice_AEP & & $\begin{array}{l}-0.0239 \\
(0.0368)\end{array}$ & & \\
\hline GasPrice_Duke & & $\begin{array}{l}-0.0303 \\
(0.0516)\end{array}$ & & \\
\hline GasPrice_DP\&L & & $\begin{array}{l}-0.0512 * * * \\
(0.0118)\end{array}$ & & \\
\hline Deregulation_GasPrice & $\begin{array}{l}-0.242 * * \\
(0.0879)\end{array}$ & & & \\
\hline Deregulation_GasPrice_FirstEnergy & & $\begin{array}{l}-0.138 \\
(0.0865)\end{array}$ & & \\
\hline Deregulation_GasPrice_AEP & & $\begin{array}{l}-0.637 * * * \\
(0.126)\end{array}$ & & \\
\hline Deregulation_GasPrice_Duke & & $\begin{array}{c}0.342 * \\
(0.166)\end{array}$ & & \\
\hline Deregulation_GasPrice_DP\&L & & $\begin{array}{c}0.339 \\
(0.203)\end{array}$ & & \\
\hline CoalDeliv_Price & $\begin{array}{c}0.0135 \\
(0.596)\end{array}$ & $\begin{array}{c}0.517 \\
(0.469)\end{array}$ & & \\
\hline$L M P$ & & & $\begin{array}{l}-0.00119 \\
(0.00531)\end{array}$ & \\
\hline LMP_FirstEnergy & & & & $\begin{array}{c}0.0221 * * \\
(0.00785)\end{array}$ \\
\hline$L M P \_A E P$ & & & & $\begin{array}{l}-0.0011 \\
(0.00697)\end{array}$ \\
\hline LMP_Duke & & & & $\begin{array}{l}-0.0262 \\
(0.0151)\end{array}$ \\
\hline$L M P \_D P \& L$ & & & & $\begin{array}{l}-0.0110^{*} \\
(0.00543)\end{array}$ \\
\hline Deregulation_LMP & & & $\begin{array}{l}-0.0292 * * \\
(0.00991)\end{array}$ & \\
\hline Deregulation_LMP_FirstEnergy & & & & $\begin{array}{l}-0.0569 * * * \\
(0.0133)\end{array}$ \\
\hline Deregulation_LMP_AEP & & & & $\begin{array}{l}-0.0470 * * \\
(0.0161)\end{array}$ \\
\hline Deregulation_LMP_Duke & & & & $\begin{array}{c}0.0225 \\
(0.0281)\end{array}$ \\
\hline Deregulation_LMP_DP\&L & & & & $\begin{array}{c}0.0271 \\
(0.0215)\end{array}$ \\
\hline
\end{tabular}




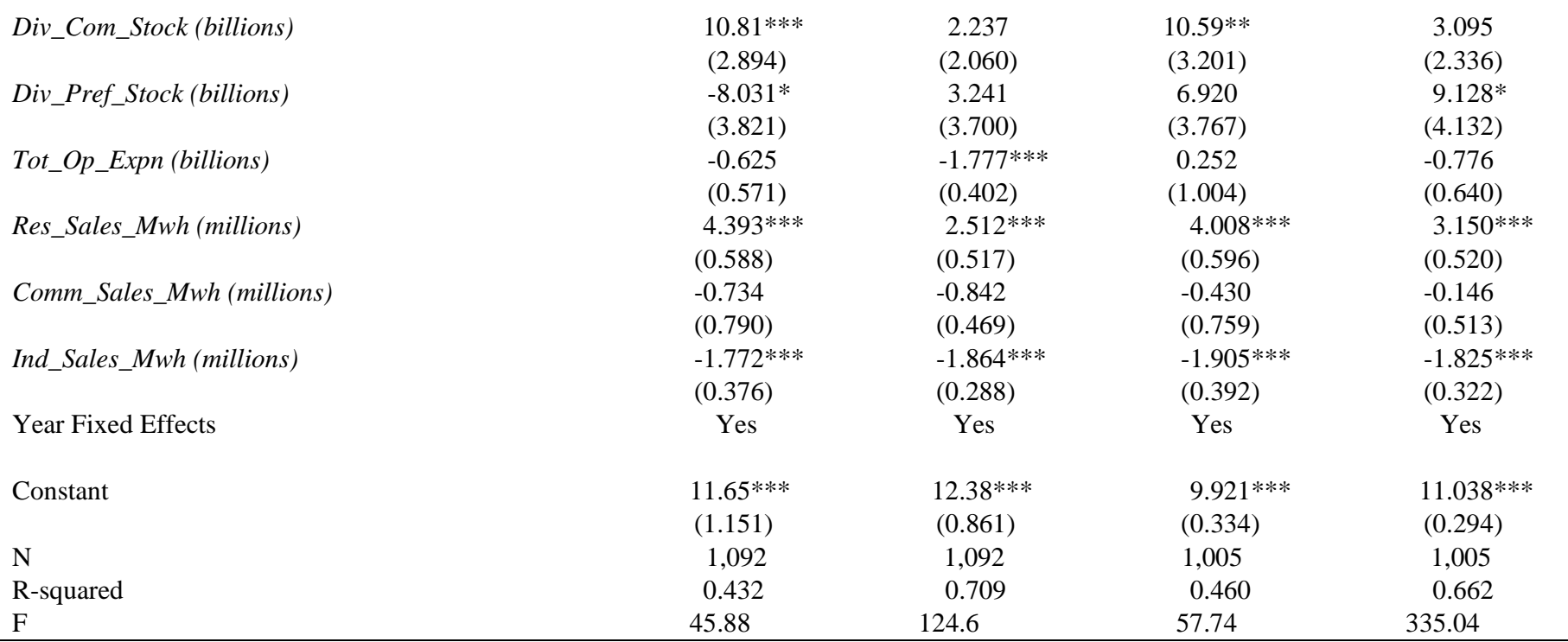

Models report fixed effects panel regression estimates with Driscoll-Kraay standard errors using the $x t s c c$ subroutine in Stata 14. All models include year fixed effects. Standard errors are provided in parentheses. $* * * \mathrm{p}<0.01, * * \mathrm{p}<0.05, * \mathrm{p}<0.1$ 
Table A2. Regression Analysis of Retail Price (Industrial Bills)

\begin{tabular}{|c|c|c|c|c|}
\hline INDUSTRIAL MARGINAL PRICE & $\begin{array}{c}(1) \\
\text { XTSCC } \\
\end{array}$ & $\begin{array}{c}(2) \\
\text { XTSCC-I } \\
\end{array}$ & $\begin{array}{c}(3) \\
\text { XTSCC } \\
\end{array}$ & $\begin{array}{c}(4) \\
\text { XTSCC-I } \\
\end{array}$ \\
\hline Deregulation & $\begin{array}{c}1.205 \\
(0.650)\end{array}$ & & $\begin{array}{c}0.907 \\
(0.638)\end{array}$ & \\
\hline Deregulation_FirstEnergy & & $\begin{array}{l}-3.596 * * * \\
(0.732)\end{array}$ & & $\begin{array}{l}-2.804 * * \\
(0.791)\end{array}$ \\
\hline Deregulation_AEP & & $\begin{array}{l}3.119 * * * \\
(0.687)\end{array}$ & & $\begin{array}{l}2.745^{* * * *} \\
(0.579)\end{array}$ \\
\hline Deregulation_Duke & & $\begin{array}{l}-2.468 * * \\
(1.001)\end{array}$ & & $\begin{array}{l}-2.977 * \\
(1.224)\end{array}$ \\
\hline Deregulation_DP\&L & & $\begin{array}{c}0.906 \\
(0.869)\end{array}$ & & $\begin{array}{c}1.335 \\
(0.925)\end{array}$ \\
\hline NatGasDeliv_Price & $\begin{array}{l}-0.0205 \\
(0.0201)\end{array}$ & & & \\
\hline GasPrice_FirstEnergy & & $\begin{array}{l}-0.0225 \\
(0.0254)\end{array}$ & & \\
\hline GasPrice_AEP & & $\begin{array}{l}-0.0171 \\
(0.0299)\end{array}$ & & \\
\hline GasPrice_Duke & & $\begin{array}{l}-0.0789 \\
(0.0572)\end{array}$ & & \\
\hline GasPrice_DP\&L & & $\begin{array}{r}0.00565 \\
(0.0353)\end{array}$ & & \\
\hline Deregulation_GasPrice & $\begin{array}{l}-0.172 \\
(0.0969)\end{array}$ & & & \\
\hline Deregulation_GasPrice_FirstEnergy & & $\begin{array}{l}-0.0784 \\
(0.123)\end{array}$ & & \\
\hline Deregulation_GasPrice_AEP & & $\begin{array}{l}-0.475 * * * \\
(0.0927)\end{array}$ & & \\
\hline Deregulation_GasPrice_Duke & & $\begin{array}{l}0.457 * * \\
(0.149)\end{array}$ & & \\
\hline Deregulation_GasPrice_DP\&L & & $\begin{array}{c}0.145 \\
(0.172)\end{array}$ & & \\
\hline CoalDeliv_Price & $\begin{array}{c}0.353 \\
(0.552)\end{array}$ & $\begin{array}{l}0.915^{* *} \\
(0.340)\end{array}$ & & \\
\hline$L M P$ & & & $\begin{array}{l}-0.00985 \\
(0.00698)\end{array}$ & \\
\hline LMP_FirstEnergy & & & & $\begin{array}{c}0.00155 \\
(0.00572)\end{array}$ \\
\hline$L M P \_A E P$ & & & & $\begin{array}{c}0.00321 \\
(0.00568)\end{array}$ \\
\hline LMP_Duke & & & & $\begin{array}{l}-0.0417 * * \\
(0.0159)\end{array}$ \\
\hline$L M P \_D P \& L$ & & & & $\begin{array}{c}0.000546 \\
(0.00847)\end{array}$ \\
\hline Deregulation_LMP & & & $\begin{array}{l}-0.0111 \\
(0.0112)\end{array}$ & \\
\hline Deregulation_LMP_FirstEnergy & & & & $\begin{array}{l}-0.0203 \\
(0.0146)\end{array}$ \\
\hline Deregulation_LMP_AEP & & & & $\begin{array}{l}-0.0437 * * * \\
(0.0116)\end{array}$ \\
\hline Deregulation_LMP_Duke & & & & $\begin{array}{c}0.0601 * \\
(0.0258)\end{array}$ \\
\hline Deregulation_LMP_DP\&L & & & & $\begin{array}{c}0.00286 \\
(0.0174)\end{array}$ \\
\hline Div_Com_Stock (billions) & $\begin{array}{c}7.299 * \\
(3.304)\end{array}$ & $\begin{array}{l}-4.543 \\
(2.643)\end{array}$ & $\begin{array}{l}9.182 * * \\
(3.517)\end{array}$ & $\begin{array}{l}-1.464 \\
(2.445)\end{array}$ \\
\hline
\end{tabular}




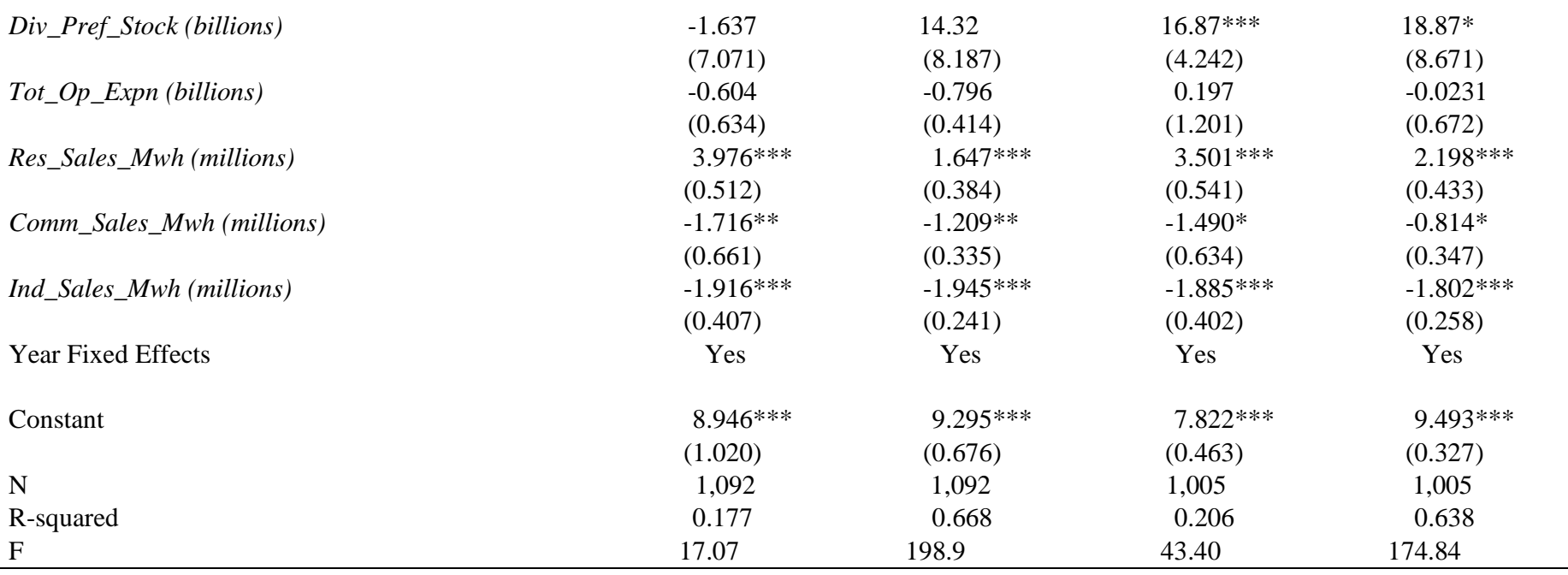

Models report fixed effects panel regression estimates with Driscoll-Kraay standard errors using the $x t s c c$ subroutine in Stata 14 . All models include year fixed effects. Standard errors are provided in parentheses. $* * * \mathrm{p}<0.01, * * \mathrm{p}<0.05, * \mathrm{p}<0.1$ 
Table A3. Regression Analysis of Retail Price (Commercial Bills)

\begin{tabular}{|c|c|c|c|c|}
\hline COMMERCIAL MARGINAL PRICE & $\begin{array}{c}(1) \\
\text { XTSCC } \\
\end{array}$ & $\begin{array}{c}(2) \\
\text { XTSCC-I } \\
\end{array}$ & $\begin{array}{c}(3) \\
\text { XTSCC } \\
\end{array}$ & $\begin{array}{c}(4) \\
\text { XTSCC-I } \\
\end{array}$ \\
\hline Deregulation & $\begin{array}{l}1.700 * * \\
(0.584)\end{array}$ & & $\begin{array}{c}1.285^{*} \\
(0.535)\end{array}$ & \\
\hline Deregulation_FirstEnergy & & $\begin{array}{l}-1.828 * * \\
(0.630)\end{array}$ & & $\begin{array}{l}-0.363 \\
(0.767)\end{array}$ \\
\hline Deregulation_AEP & & $\begin{array}{l}4.273 * * * \\
(0.658)\end{array}$ & & $\begin{array}{l}3.381 * * * \\
(0.654)\end{array}$ \\
\hline Deregulation_Duke & & $\begin{array}{l}-1.304 \\
(0.901)\end{array}$ & & $\begin{array}{l}-2.355^{*} \\
(1.104)\end{array}$ \\
\hline Deregulation_DP\&L & & $\begin{array}{c}0.249 \\
(0.831)\end{array}$ & & $\begin{array}{l}-0.0033 \\
(0.911)\end{array}$ \\
\hline NatGasDeliv_Price & $\begin{array}{l}-0.0417 \\
(0.0217)\end{array}$ & & & \\
\hline GasPrice_FirstEnergy & & $\begin{array}{l}-0.0585^{*} \\
(0.0277)\end{array}$ & & \\
\hline GasPrice_AEP & & $\begin{array}{l}-0.0191 \\
(0.0395)\end{array}$ & & \\
\hline GasPrice_Duke & & $\begin{array}{l}-0.0677 \\
(0.0529)\end{array}$ & & \\
\hline GasPrice_DP\&L & & $\begin{array}{l}-0.0434 * * \\
(0.0136)\end{array}$ & & \\
\hline Deregulation_GasPrice & $\begin{array}{l}-0.267 * * \\
(0.0797)\end{array}$ & & & \\
\hline Deregulation_GasPrice_FirstEnergy & & $\begin{array}{l}-0.172 \\
(0.0938)\end{array}$ & & \\
\hline Deregulation_GasPrice_AEP & & $\begin{array}{l}-0.621 * * * \\
(0.0938)\end{array}$ & & \\
\hline Deregulation_GasPrice_Duke & & $\begin{array}{l}0.359 * * \\
(0.143)\end{array}$ & & \\
\hline Deregulation_GasPrice_DP\&L & & $\begin{array}{c}0.203 \\
(0.163)\end{array}$ & & \\
\hline CoalDeliv_Price & $\begin{array}{c}0.0785 \\
(0.571)\end{array}$ & $\begin{array}{c}0.589 \\
(0.381)\end{array}$ & & \\
\hline$L M P$ & & & $\begin{array}{l}-0.00684 \\
(0.0054)\end{array}$ & \\
\hline LMP_FirstEnergy & & & & $\begin{array}{c}0.01037 \\
(0.00675)\end{array}$ \\
\hline$L M P \_A E P$ & & & & $\begin{array}{c}0.00262 \\
(0.00780)\end{array}$ \\
\hline LMP_Duke & & & & $\begin{array}{l}-0.0392 * * \\
(0.0155)\end{array}$ \\
\hline$L M P \_D P \& L$ & & & & $\begin{array}{l}-0.0119 * \\
(0.00497)\end{array}$ \\
\hline Deregulation_LMP & & & $\begin{array}{l}-0.0230 * \\
(0.00989)\end{array}$ & \\
\hline Deregulation_LMP_FirstEnergy & & & & $\begin{array}{l}-0.0425 * * \\
(0.0150)\end{array}$ \\
\hline Deregulation_LMP_AEP & & & & $\begin{array}{l}-0.0517 * * \\
(0.0139)\end{array}$ \\
\hline Deregulation_LMP_Duke & & & & $\begin{array}{c}0.0562 * \\
(0.0252)\end{array}$ \\
\hline Deregulation_LMP_DP\&L & & & & $\begin{array}{c}0.0215 \\
(0.0181)\end{array}$ \\
\hline Div_Com_Stock (billions) & $\begin{array}{l}11.12 * * * \\
(2.860)\end{array}$ & $\begin{array}{c}1.679 \\
(1.709)\end{array}$ & $\begin{array}{c}11.13 * * \\
(3.193)\end{array}$ & $\begin{array}{c}2.889 \\
(1.931)\end{array}$ \\
\hline
\end{tabular}




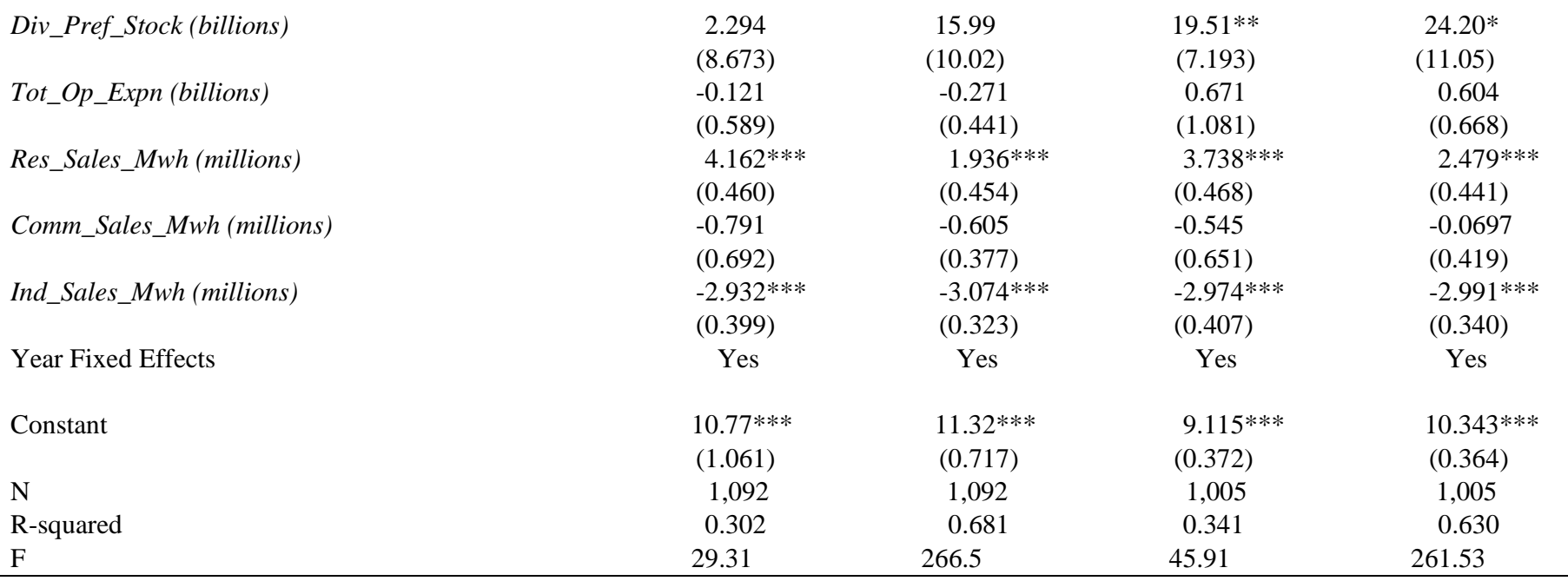

Models report fixed effects panel regression estimates with Driscoll-Kraay standard errors using the $x t s c c$ subroutine in Stata 14. All models include year fixed effects. Standard errors are provided in parentheses. *** $\mathrm{p}<0.01, * * \mathrm{p}<0.05, * \mathrm{p}<0.1$ 
Table A4. Regression Analysis of Residential/Industrial Marginal Price Ratio

\begin{tabular}{|c|c|c|c|c|}
\hline $\begin{array}{l}\text { RESIDENTIAL/INDUSTRIAL MARGINAL PRICE } \\
\text { RATIO }\end{array}$ & $\begin{array}{c}(1) \\
\text { XTSCC } \\
\end{array}$ & $\begin{array}{c}(2) \\
\text { XTSCC-I } \\
\end{array}$ & $\begin{array}{c}(3) \\
\text { XTSCC } \\
\end{array}$ & $\begin{array}{l}(4) \\
\text { XTSCC-I } \\
\end{array}$ \\
\hline Deregulation & $\begin{array}{l}-0.0736 \\
(0.0532)\end{array}$ & & $\begin{array}{l}-0.0514 \\
(0.0533)\end{array}$ & \\
\hline Deregulation_FirstEnergy & & $\begin{array}{c}0.143 \\
(0.0911)\end{array}$ & & $\begin{array}{c}0.236 * * \\
(0.0834)\end{array}$ \\
\hline Deregulation_AEP & & $\begin{array}{l}-0.0234 \\
(0.0720)\end{array}$ & & $\begin{array}{l}-0.109 \\
(0.0853)\end{array}$ \\
\hline Deregulation_Duke & & $\begin{array}{c}0.130 \\
(0.0963)\end{array}$ & & $\begin{array}{c}0.224 \\
(0.119)\end{array}$ \\
\hline Deregulation_DP\&L & & $\begin{array}{l}-0.255^{* *} \\
(0.0690)\end{array}$ & & $\begin{array}{l}-0.286 * * \\
(0.0801)\end{array}$ \\
\hline NatGasDeliv_Price & $\begin{array}{l}-0.00128 \\
(0.00205)\end{array}$ & & & \\
\hline GasPrice_FirstEnergy & & $\begin{array}{l}-0.00499 \\
(0.00317)\end{array}$ & & \\
\hline GasPrice_AEP & & $\begin{array}{r}0.000281 \\
(0.00198)\end{array}$ & & \\
\hline GasPrice_Duke & & $\begin{array}{c}0.0120 \\
(0.00659)\end{array}$ & & \\
\hline GasPrice_DP\&L & & $\begin{array}{l}-0.00614 \\
(0.00522)\end{array}$ & & \\
\hline Deregulation_GasPrice & $\begin{array}{l}-0.00516 \\
(0.00803)\end{array}$ & & & \\
\hline Deregulation_GasPrice_FirstEnergy & & $\begin{array}{c}0.00326 \\
(0.0141)\end{array}$ & & \\
\hline Deregulation_GasPrice_AEP & & $\begin{array}{l}-0.0175 \\
(0.0121)\end{array}$ & & \\
\hline Deregulation_GasPrice_Duke & & $\begin{array}{l}-0.0347 * * \\
(0.0135)\end{array}$ & & \\
\hline Deregulation_GasPrice_DP\&L & & $\begin{array}{l}0.0274 * * \\
(0.0109)\end{array}$ & & \\
\hline CoalDeliv_Price & $\begin{array}{l}-0.0457 \\
(0.0517)\end{array}$ & $\begin{array}{l}-0.0583 \\
(0.0492)\end{array}$ & & \\
\hline$L M P$ & & & $\begin{array}{c}0.00103 * \\
(0.000521)\end{array}$ & \\
\hline LMP_FirstEnergy & & & & $\begin{array}{c}0.00116 \\
(0.000674)\end{array}$ \\
\hline$L M P \_A E P$ & & & & $\begin{array}{l}-0.000547 \\
(0.000291)\end{array}$ \\
\hline LMP_Duke & & & & $\begin{array}{l}0.00435^{* *} \\
(0.00169)\end{array}$ \\
\hline$L M P \_D P \& L$ & & & & $\begin{array}{l}-0.00132 \\
(0.00129)\end{array}$ \\
\hline Deregulation_LMP & & & $\begin{array}{l}-0.00157 \\
(0.000865)\end{array}$ & \\
\hline Deregulation_LMP_FirstEnergy & & & & $\begin{array}{l}-0.00146 \\
(0.00166)\end{array}$ \\
\hline Deregulation_LMP_AEP & & & & $\begin{array}{l}-0.000818 \\
(0.00178)\end{array}$ \\
\hline Deregulation_LMP_Duke & & & & $\begin{array}{l}-0.00732 * * \\
(0.00226)\end{array}$ \\
\hline Deregulation_LMP_DP\&L & & & & $\begin{array}{c}0.00329 * \\
(0.00154)\end{array}$ \\
\hline Div_Com_Stock (billions) & $\begin{array}{l}-0.0605 \\
(0.262)\end{array}$ & $\begin{array}{l}0.622 * * \\
(0.231)\end{array}$ & $\begin{array}{l}-0.253 \\
(0.274)\end{array}$ & $\begin{array}{c}0.432 \\
(0.229)\end{array}$ \\
\hline
\end{tabular}




\begin{tabular}{|c|c|c|c|c|}
\hline Div_Pref_Stock(billions) & $\begin{array}{l}-1.090 * \\
(0.479)\end{array}$ & $\begin{array}{l}-1.917 * * \\
(0.580)\end{array}$ & $\begin{array}{l}-2.190 * * * \\
(0.365)\end{array}$ & $\begin{array}{l}-2.216 * * * \\
(0.543)\end{array}$ \\
\hline \multirow[t]{2}{*}{ Tot_Op_Expn (billions) } & $-0.124 *$ & $-0.171 * *$ & -0.150 & $-0.191 *$ \\
\hline & $(0.0616)$ & $(0.0654)$ & $(0.105)$ & $(0.0875)$ \\
\hline \multirow[t]{2}{*}{ Res_Sales_Mwh(millions) } & 0.0446 & $0.102 * *$ & 0.0614 & $0.125 * *$ \\
\hline & $(0.0554)$ & $(0.0415)$ & $(0.0557)$ & $(0.0491)$ \\
\hline \multirow[t]{2}{*}{ Ind_Sales_Mwh (millions) } & $0.100 * *$ & 0.0600 & $0.0989 * *$ & $0.0693 *$ \\
\hline & $(0.0391)$ & $(0.0311)$ & $(0.0387)$ & $(0.0316)$ \\
\hline Year Fixed Effects & Yes & Yes & Yes & Yes \\
\hline \multirow[t]{2}{*}{ Constant } & $1.424 * * *$ & $1.439 * * *$ & $1.408 * * *$ & $1.301 * * *$ \\
\hline & $(0.0937)$ & $(0.0906)$ & $(0.0416)$ & $(0.0333)$ \\
\hline $\mathrm{N}$ & 1,092 & 1,092 & 1,005 & 1,005 \\
\hline R-squared & 0.362 & 0.558 & 0.371 & 0.559 \\
\hline $\mathrm{F}$ & 60.55 & 84.90 & 61.93 & 68.87 \\
\hline
\end{tabular}

Models report fixed effects panel regression estimates with Driscoll-Kraay standard errors using the $x t s c c$ subroutine in Stata 14. All models include year fixed effects. Standard errors are provided in parentheses. $* * * p<0.01, * * p<0.05, * p<0.1$ 
Table A5. Regression Analysis of Residential/Commercial Marginal Price Ratio

\begin{tabular}{|c|c|c|c|c|}
\hline $\begin{array}{l}\text { RESIDENTIAL/COMMERCIAL MARGINAL } \\
\text { PRICE RATIO }\end{array}$ & $\begin{array}{c}(1) \\
\text { XTSCC } \\
\end{array}$ & $\begin{array}{c}(2) \\
\text { XTSCC-I } \\
\end{array}$ & $\begin{array}{c}(3) \\
\text { XTSCC } \\
\end{array}$ & $\begin{array}{c}(4) \\
\text { XTSCC-I } \\
\end{array}$ \\
\hline Deregulation & $\begin{array}{l}-0.0623 * * \\
(0.0171)\end{array}$ & & $\begin{array}{l}-0.0362 * \\
(0.0172)\end{array}$ & \\
\hline Deregulation_FirstEnergy & & $\begin{array}{l}-0.0155 \\
(0.0367)\end{array}$ & & $\begin{array}{c}0.0360 \\
(0.0332)\end{array}$ \\
\hline Deregulation_AEP & & $\begin{array}{l}-0.0614 \\
(0.0438)\end{array}$ & & $\begin{array}{l}-0.0711 \\
(0.0491)\end{array}$ \\
\hline Deregulation_Duke & & $\begin{array}{l}-0.0101 \\
(0.0524)\end{array}$ & & $\begin{array}{c}0.0774 \\
(0.0592)\end{array}$ \\
\hline Deregulation_DP\&L & & $\begin{array}{l}-0.0983 * * * \\
(0.0261)\end{array}$ & & $\begin{array}{l}-0.0816 * * \\
(0.0235)\end{array}$ \\
\hline NatGasDeliv_Price & $\begin{array}{c}0.000418 \\
(0.000848)\end{array}$ & & & \\
\hline GasPrice_FirstEnergy & & $\begin{array}{l}-0.00143 \\
(0.00142)\end{array}$ & & \\
\hline GasPrice_AEP & & $\begin{array}{r}0.000620 \\
(0.00183)\end{array}$ & & \\
\hline GasPrice_Duke & & $\begin{array}{c}0.00531 \\
(0.00323)\end{array}$ & & \\
\hline GasPrice_DP\&L & & $\begin{array}{r}0.000389 \\
(0.00166)\end{array}$ & & \\
\hline Deregulation_GasPrice & $\begin{array}{c}0.00395 \\
(0.00262)\end{array}$ & & & \\
\hline Deregulation_GasPrice_FirstEnergy & & $\begin{array}{c}0.00816 \\
(0.00565)\end{array}$ & & \\
\hline Deregulation_GasPrice_AEP & & $\begin{array}{l}-0.000565 \\
(0.00767)\end{array}$ & & \\
\hline Deregulation_GasPrice_Duke & & $\begin{array}{l}-0.00992 \\
(0.00677)\end{array}$ & & \\
\hline Deregulation_GasPrice_DP\&L & & $\begin{array}{r}0.0114 * * \\
(0.00458)\end{array}$ & & \\
\hline CoalDeliv_Price & $\begin{array}{l}-0.0115 \\
(0.0206)\end{array}$ & $\begin{array}{l}-0.0186 \\
(0.0190)\end{array}$ & & \\
\hline$L M P$ & & & $\begin{array}{c}0.000576 * * \\
(0.000221)\end{array}$ & \\
\hline LMP_FirstEnergy & & & & $\begin{array}{c}0.000699 * \\
(0.000319)\end{array}$ \\
\hline$L M P \_A E P$ & & & & $\begin{array}{l}-0.0000553 \\
(0.000396)\end{array}$ \\
\hline LMP_Duke & & & & $\begin{array}{l}0.00161 \\
(0.000867)\end{array}$ \\
\hline$L M P \_D P \& L$ & & & & $\begin{array}{l}0.00000430 \\
(0.000262)\end{array}$ \\
\hline Deregulation_LMP & & & $\begin{array}{l}-0.000267 \\
(0.000346)\end{array}$ & \\
\hline Deregulation_LMP_FirstEnergy & & & & $\begin{array}{r}0.0000427 \\
(0.000763)\end{array}$ \\
\hline Deregulation_LMP_AEP & & & & $\begin{array}{l}0.0000197 \\
(0.00113)\end{array}$ \\
\hline Deregulation_LMP_Duke & & & & $\begin{array}{l}-0.00362 * * \\
(0.00112)\end{array}$ \\
\hline Deregulation_LMP_DP\&L & & & & $\begin{array}{c}0.000792 \\
(0.000457)\end{array}$ \\
\hline Div_Com_Stock (billions) & $\begin{array}{l}-0.163 \\
(0.166)\end{array}$ & $\begin{array}{c}0.0438 \\
(0.133)\end{array}$ & $\begin{array}{l}-0.189 \\
(0.174)\end{array}$ & $\begin{array}{l}0.00976 \\
(0.134)\end{array}$ \\
\hline
\end{tabular}




\begin{tabular}{|c|c|c|c|c|}
\hline Div_Pref_Stock(billions) & $\begin{array}{c}0.162 \\
(0.663)\end{array}$ & $\begin{array}{l}-0.225 \\
(0.718)\end{array}$ & $\begin{array}{l}0.000838 \\
(0.770)\end{array}$ & $\begin{array}{l}-0.204 \\
(0.937)\end{array}$ \\
\hline Tot_Op_Expn (billions) & $\begin{array}{l}-0.0696 * * \\
(0.0282)\end{array}$ & $\begin{array}{l}-0.116^{* *} \\
(0.0346)\end{array}$ & $\begin{array}{c}-0.0662 \\
(0.0360)\end{array}$ & $\begin{array}{l}-0.108 * * \\
(0.0391)\end{array}$ \\
\hline Res_Sales_Mwh (millions) & $\begin{array}{l}-0.0115 \\
(0.0365)\end{array}$ & $\begin{array}{c}0.0302 \\
(0.0319)\end{array}$ & $\begin{array}{l}-0.00910 \\
(0.0357)\end{array}$ & $\begin{array}{c}0.0332 \\
(0.0347)\end{array}$ \\
\hline Comm_Sales_Mwh (millions) & $\begin{array}{l}0.0951^{* *} \\
(0.0257)\end{array}$ & $\begin{array}{c}0.0611^{*} \\
(0.0293)\end{array}$ & $\begin{array}{l}0.0961 * * \\
(0.0257)\end{array}$ & $\begin{array}{c}0.0707 * \\
(0.0289)\end{array}$ \\
\hline Year Fixed Effects & Yes & Yes & Yes & Yes \\
\hline Constant & $\begin{array}{l}1.167 * * * \\
(0.0374)\end{array}$ & $\begin{array}{l}1.181 * * * \\
(0.0344)\end{array}$ & $\begin{array}{l}1.153 * * * \\
(0.0243)\end{array}$ & $\begin{array}{l}1.125 * * * \\
(0.0286)\end{array}$ \\
\hline $\mathrm{N}$ & 1,092 & 1,092 & 1,005 & 1,005 \\
\hline R-squared & 0.257 & 0.354 & 0.265 & 0.352 \\
\hline $\mathrm{F}$ & 40.01 & 58.87 & 45.61 & 52.75 \\
\hline
\end{tabular}

Models report fixed effects panel regression estimates with Driscoll-Kraay standard errors using the $x t s c c$ subroutine in Stata 14. All models include year fixed effects. Standard errors are provided in parentheses. $* * * \mathrm{p}<0.01, * * \mathrm{p}<0.05,{ }^{*} \mathrm{p}<0.1$ 


\section{Appendix B. Supplemental Figures (for reviewers only)}

\section{Price (Constant 2016\$)}
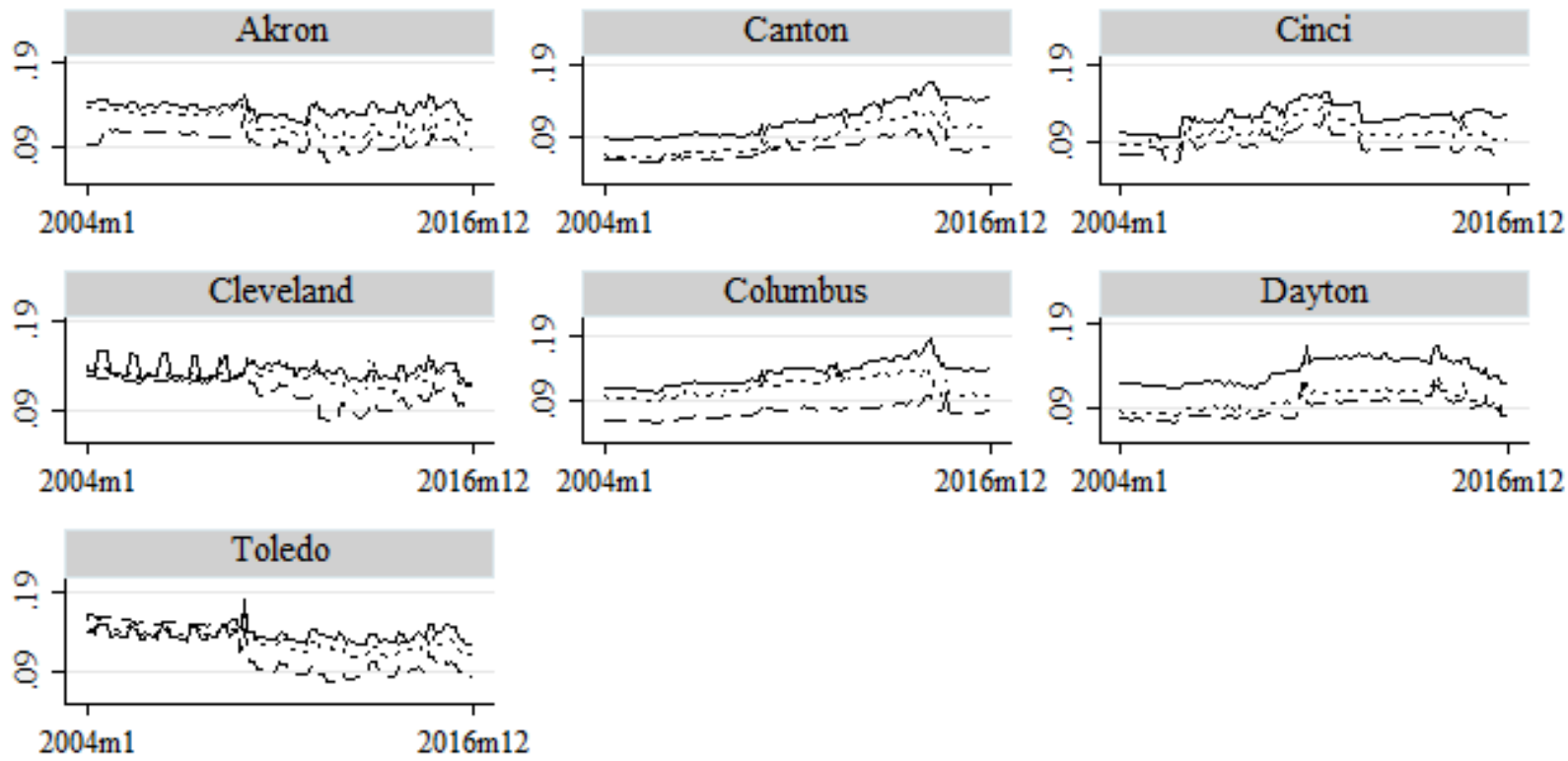

\section{Date}

$\begin{array}{ll} & \text { Price_Residential } \\ \ldots . . . . . . & \text { Price_Commercial }\end{array}$

Graphs by City

Figure A1. Marginal Price of Representative, Total Electric Bill (by class and metro area)

Note: Figure provides the monthly inflation-corrected marginal price by customer class for each of the seven major metro areas in the state of Ohio over the period 2004-2016. 


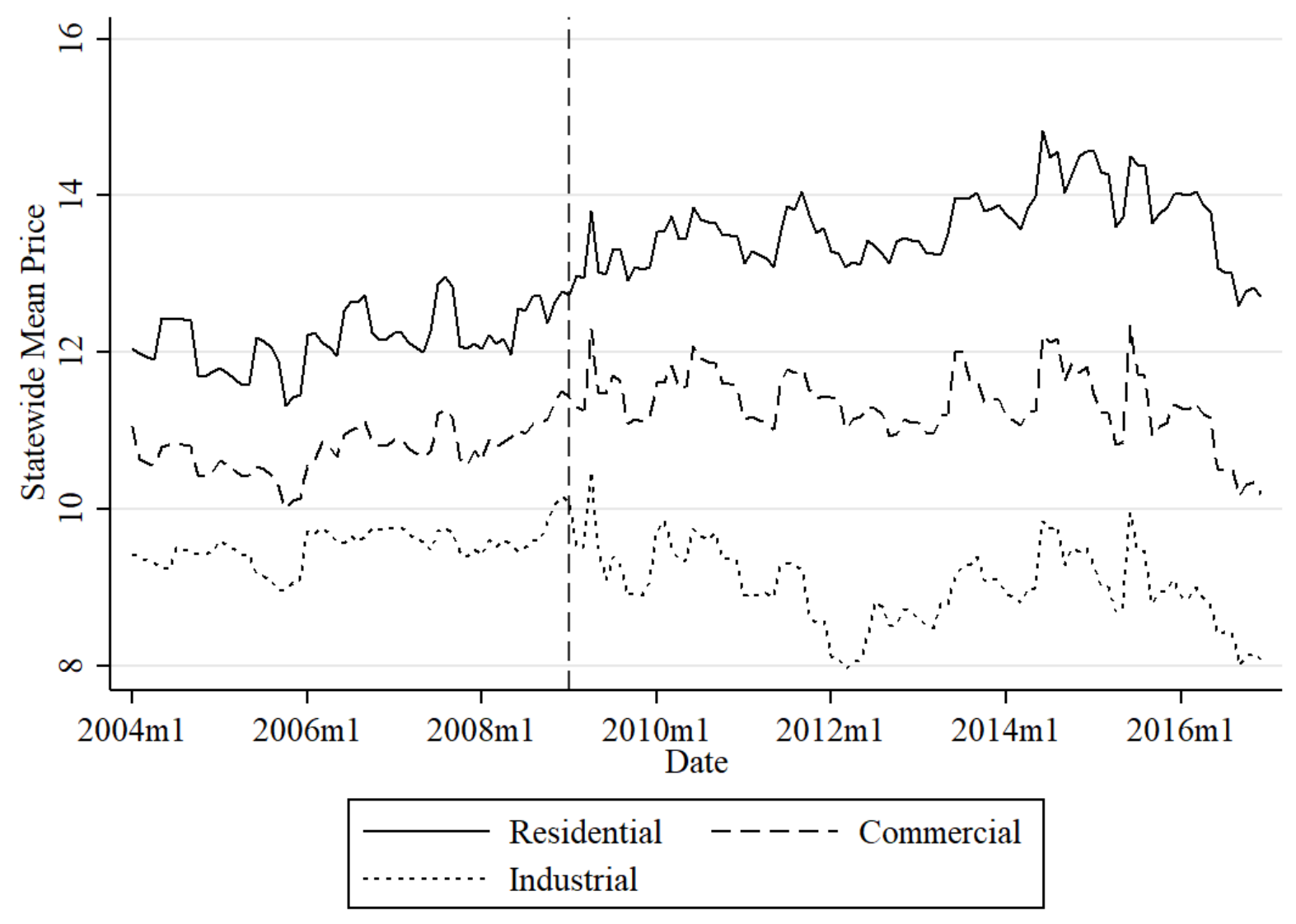

Figure A2. Statewide Mean Electricity Price

Note: Figure provides the mean monthly inflation-corrected statewide aggregate electricity prices by customer class. The vertical indicator bar identifies the implementation of retail electric restructuring beginning January, 2009. 


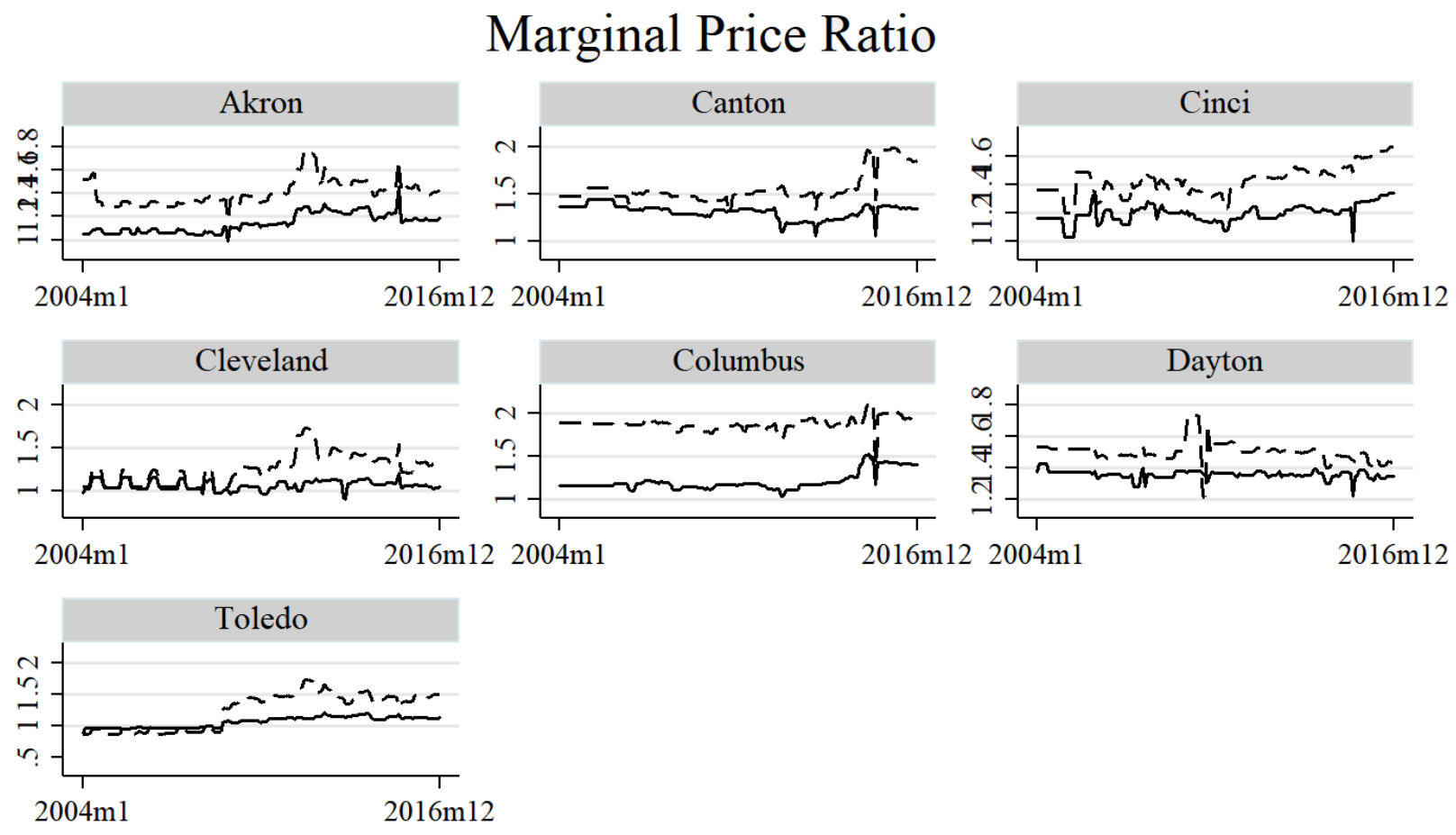

Date

\section{Residential/Commercial Ratio _ - - - - Residential/Industrial Ratio}

Graphs by City

Figure A3. Inter-Class Marginal Price Ratios (by metro area)

Note: Figure provides the monthly marginal price ratios by major metro area. 